Prepared in cooperation with the Shakopee Mdewakanton Sioux Community

\title{
Hydraulic Properties of the Ironton and Galesville Sandstones, Shakopee Mdewakanton Sioux Community, Southeastern Minnesota, 2004
}

Scientific Investigations Report 2005-5245 


\section{Hydraulic Properties of the Ironton and Galesville Sandstones, Shakopee Mdewakanton Sioux Community, Southeastern Minnesota, 2004}

By Thomas A. Winterstein

Prepared in cooperation with the Shakopee Mdewakanton Sioux Community

Scientific Investigations Report 2005-5245 


\section{U.S. Department of the Interior \\ Gale A. Norton, Secretary}

\section{U.S. Geological Survey \\ P. Patrick Leahy, Acting Director}

U.S. Geological Survey, Reston, Virginia: 2005

For sale by U.S. Geological Survey, Information Services
Box 25286, Denver Federal Center
Denver, CO 80225
For more information about the USGS and its products:
Telephone: 1-888-ASK-USGS
World Wide Web: http://www.usgs.gov/

Any use of trade, product, or firm names in this publication is for descriptive purposes only and does not imply endorsement by the U.S. Government.

Although this report is in the public domain, permission must be secured from the individual copyright owners to reproduce any copyrighted materials contained within this report.

Suggested citation:

Winterstein, T.A., 2005, Hydraulic properties of the Ironton and Galesville Sandstones, Shakopee Mdewakanton Sioux Community, southeastern Minnesota, 2004: U.S. Geological Survey Scientific Investigations Report 2005-5245, 30 p.

Prepared by U.S. Geological Survey in Mounds View, Minnesota (http://mn.water.usgs.gov) 


\section{Contents}

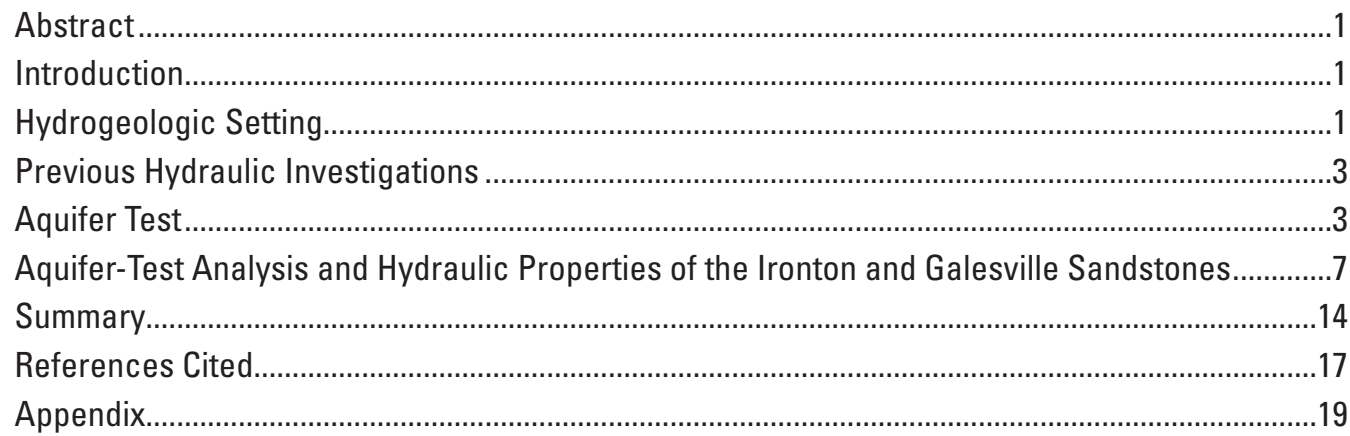

\section{Figures}

1. Map showing location of study area, production well, and two observation wells, Shakopee Mdewakanton Sioux Community, southeastern Minnesota

2. Comparison chart showing lithology beneath production well and two observation wells

3-10. Graphs showing:

3. Recorded water levels during aquifer test for production well, December 6-22, 2004, measured water levels in production well, December 9, 2004, and comparison of measured and recorded water levels during production well recovery, December 9 , 2004.

4. Recorded water levels in observation wells 1 and 2, November 26-December 22, 2004 ...

5. Recorded water levels in observation wells 1 and 2 and recorded barometric pressure at observation well 1 before aquifer test, November 26-December 6, 2004........8

6. Predicted changes in water levels in observation wells 1 and 2 due to changes in barometric pressure during aquifer test, November 26-December 22, 2004

7. Theis and Hantush fitted type curves and recorded water levels for observation wells 1 and 2, December 6-22, 2004.

8. Hantush-Jacob and Neumann-Witherspoon fitted type curves and recorded water levels for observation wells 1 and 2, December 6-22, 2004

9. Cooper-Jacob method of solution applied to recorded drawdown of observation well 1, observation well 2, and production well, December 6-9, 2004.

10. Theis recovery method applied to residual recovery curves for observation well 1 and observation well 2, December 9-22, 2004

\section{Tables}

1. Driller's log and interpreted natural gamma borehole log of production well and driller's logs of two observation wells, Shakopee Mdewakanton Sioux Community, southeastern Minnesota

2. Measured pumping rate from production well, Shakopee Mdewakanton Sioux Community, southeastern Minnesota, December 6-9, 2004 
3. Estimated aquifer properties of Ironton and Galesville Sandstones, Shakopee Mdewakanton Sioux Community, southeastern Minnesota.....

A1. Recorded water levels in production well, Shakopee Mdewakanton Sioux Community, southeastern Minnesota, December 6-22, 2004

A2. Measured water levels in production well, Shakopee Mdewakanton Sioux Community, southeastern Minnesota, December 9, 2004

A3. Measured water levels in observation well 1 and observation well 2, Shakopee Mdewakanton Sioux Community, southeastern Minnesota, December 6-22, 2004.

\section{Conversion Factors, Abbreviations, and Datums}

\begin{tabular}{|c|c|c|}
\hline Multiply & By & To obtain \\
\hline \multicolumn{3}{|c|}{ Length } \\
\hline foot $(\mathrm{ft})$ & 0.3048 & meter $(\mathrm{m})$ \\
\hline inch (in.) & 2.54 & centimeter $(\mathrm{cm})$ \\
\hline inch (in.) & 25.4 & millimeter (mm) \\
\hline mile (mi) & 1.609 & kilometer (km) \\
\hline \multicolumn{3}{|c|}{ Volume } \\
\hline gallon (gal) & 3.785 & liter $(\mathrm{L})$ \\
\hline gallon (gal) & 0.003785 & cubic meter $\left(\mathrm{m}^{3}\right)$ \\
\hline gallon (gal) & 3.785 & cubic decimeter $\left(\mathrm{dm}^{3}\right)$ \\
\hline \multicolumn{3}{|c|}{ Flow rate } \\
\hline foot per day (ft/d) & 0.3048 & meter per day (m/d) \\
\hline foot squared per day $\left(\mathrm{ft}^{2} / \mathrm{d}\right)$ & 0.9290 & neter sqyared per day $\left(\mathrm{m}^{2} / \mathrm{d}\right)$ \\
\hline gallon per minute (gal/min) & 0.06309 & liter per second (L/s) \\
\hline \multicolumn{3}{|c|}{ Mass } \\
\hline pound per cubic foot $\left(\mathrm{lb} / \mathrm{ft}^{3}\right)$ & 16.02 & kilogram per cubic meter $\left(\mathrm{kg} / \mathrm{m}^{3}\right)$ \\
\hline \multicolumn{3}{|c|}{ Pressure } \\
\hline millimeter of mercury (mmHg) & 0.0193 & pound per square inch $\left(\mathrm{lb} / \mathrm{in}^{2}\right)$ \\
\hline pound per square inch $\left(\mathrm{lb} / \mathrm{in}^{2}\right)$ & 6.895 & kilopascal (kPa) \\
\hline
\end{tabular}

Temperature in degrees Celsius $\left({ }^{\circ} \mathrm{C}\right)$ may be converted to degrees Fahrenheit $\left({ }^{\circ} \mathrm{F}\right)$ as follows:

${ }^{\circ} \mathrm{F}=\left(1.8 \times{ }^{\circ} \mathrm{C}\right)+32$

Temperature in degrees Fahrenheit $\left({ }^{\circ} \mathrm{F}\right)$ may be converted to degrees Celsius $\left({ }^{\circ} \mathrm{C}\right)$ as follows:

${ }^{\circ} \mathrm{C}=\left({ }^{\circ} \mathrm{F}-32\right) / 1.8$

Horizontal coordinate information is referenced to the North American Datum of 1983 (NAD 83).

Vertical coordinate information is referenced to the North American Vertical Datum of 1988 (NAVD 88). 


\title{
Hydraulic Properties of the Ironton and Galesville Sandstones, Shakopee Mdewakanton Sioux Community, Southeastern Minnesota, 2004
}

\author{
By Thomas A. Winterstein
}

\section{Abstract}

The U.S. Geological Survey, in cooperation with the Shakopee Mdewakanton Sioux Community, conducted an aquifer test December 6-22, 2004, to improve definition of the hydraulic properties of the Ironton and Galesville Sandstones beneath the Shakopee Community in southeastern Minnesota. Three wells were used in the aquifer test-a production well and two observation wells, located 3,247 feet northwest of the production well and 3,049 feet southeast of the production well. The production well, completed in the Ironton and Galesville Sandstones, was pumped at about 600 gallons per minute from 10:30 a.m. on December 6, 2004, to 3:26 p.m. on December 9, 2004. Drawdown and recovery water levels were measured in all three wells.

Four curve-fitting methods and two graphical methods were used to estimate the transmissivity and storage coefficient of the Ironton and Galesville Sandstones. The four curvefitting methods were the Theis, Hantush, Hantush-Jacob, and Neumann-Witherspoon methods. These methods were applied to the drawdown and residual recovery curves of the observation wells. The two graphical methods were the Cooper-Jacob method and the Theis recovery method. The Cooper-Jacob method was applied to the drawdown curve of the production well and the drawdown curves of the two observation wells.

The Theis recovery method was applied to the residual drawdown curves of the two observation wells.

The transmissivity estimated using the six methods ranged from 450 to 650 feet squared per day. The average transmissivity for the six methods was 540 feet squared per day. The storage coefficient estimated using the six methods ranged from 4.2 to $5.7 \times 10^{-5}$. The average storage coefficient for all six methods was $5.0 \times 10^{-5}$. The hydraulic conductivity was estimated by dividing the estimated transmissivity by 45 feet. The average hydraulic conductivity for the six methods was 12.1 feet per day.

\section{Introduction}

The Ironton and Galesville Sandstones are one of the sources of water for the Shakopee Mdewakanton Sioux Community (hereinafter termed Shakopee Community), Scott County, southeastern Minnesota (fig. 1). The U.S. Geological Survey, in cooperation with the Shakopee Community, conducted an aquifer test from December 6-22, 2004, to improve definition of the hydraulic properties of the Ironton and Galesville Sandstones beneath the Shakopee Community. Information from the test will be useful to tribal officials for water-management plans, to nontribal government officials for development of regional water-management plans, and to water-resource investigators for subsequent studies on the hydraulic properties of the sandstones.

The purpose of this report is to describe the aquifer-test design and analysis and to present the hydraulic properties of the Ironton and Galesville Sandstones beneath the Shakopee Community determined from the aquifer test. The test was conducted by pumping water from an existing production well (Franconia-Ironton-Galesville Well No. 2) for 76.9 hours and measuring the drawdown in the production well and two observation wells. The recovery was measured in the observation wells for 308.5 hours (12.9 days).

\section{Hydrogeologic Setting}

The geologic units beneath the study area that were examined in this study include thick glacial sediments and six bedrock units. The bedrock units are, in descending order, the Prairie du Chien Group, the Jordan Sandstone, the St. Lawrence Formation, the Franconia Formation, the Ironton and Galesville Sandstones, and the Eau Claire Formation of Early Ordovician and Late Cambrian age (about 500 million years ago). The lithology beneath the study area was determined from driller's logs of the production well and two observation wells and from an interpretation of a natural gamma borehole $\log$ of the production well (fig. 2 and table 1). The following description of the Franconia Formation, Ironton and Galesville 


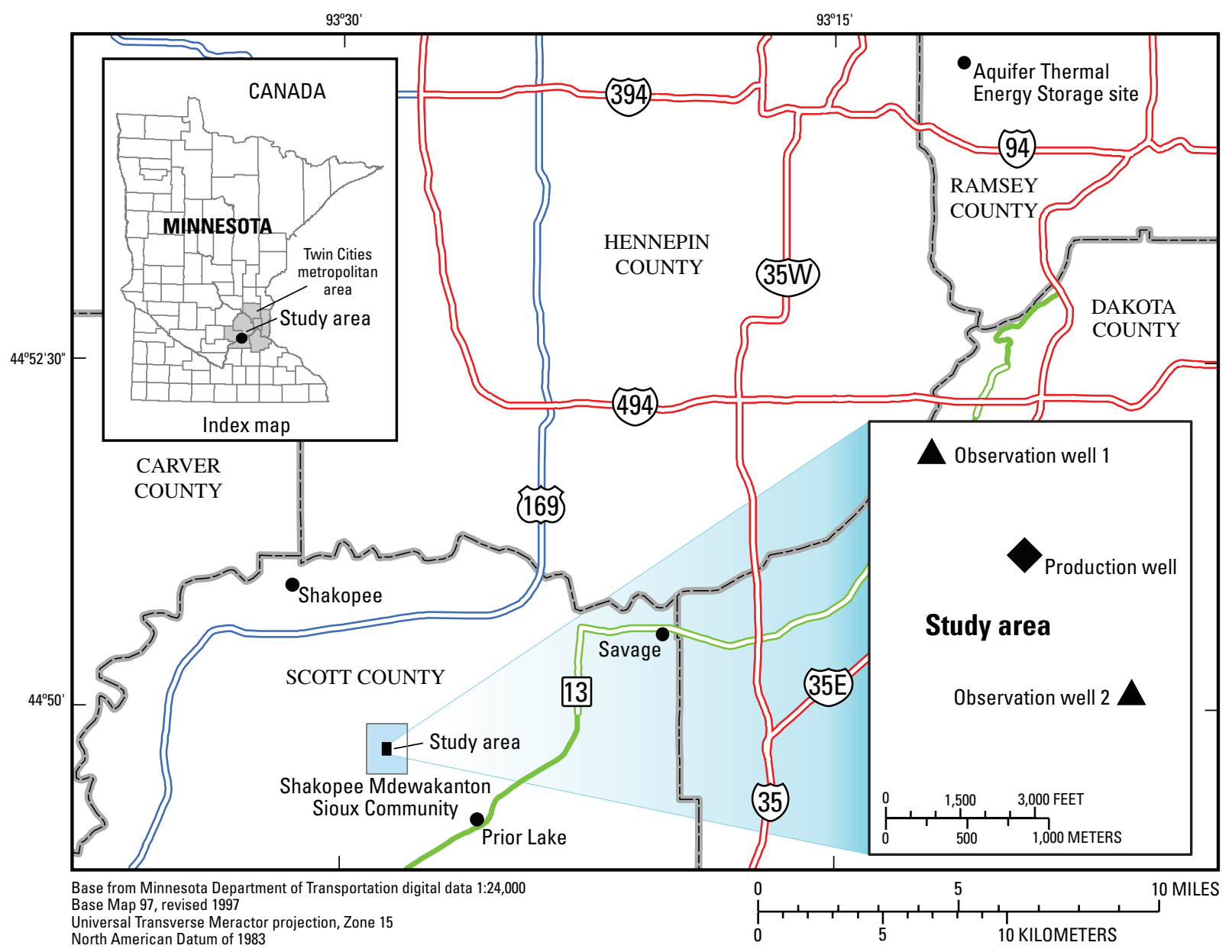

Figure 1. Location of study area, production well, and two observation wells, Shakopee Mdewakanton Sioux Community, southeastern Minnesota.

Sandstones, and the Eau Claire Formation was modified from Mossler and Tipping (2000, plate 1).

The Franconia Formation is of Late Cambrian age. In the study area, the upper part of the formation is greenishgray, medium-bedded, very fine-grained to fine-grained, dolomite-cemented, glauconitic and feldspathic sandstone and is between 133 and $159 \mathrm{ft}$ thick (table 1). The lower part of the formation consists of green-gray to light-green interbedded shale, siltstone, with lesser amounts of very fine-grained feldspathic sandstone as thick as $30 \mathrm{ft}$, which overlie darkgreen, very fine-grained to fine-grained, medium to thick beds of highly glauconitic sandstone interlayered with thin beds of gray-orange to pink sandy glauconitic dolostone, also as thick as $30 \mathrm{ft}$. The contact with the underlying Ironton Sandstone is sharply defined but apparently conformable.

The Ironton and Galesville Sandstones are of Late Cambrian age. The sandstones consist of light-gray, very fine to fine-grained feldspathic sandstone and medium- to coarsegrained and very coarse-grained, commonly cross-laminated quartz sandstone interlayered with scattered thin beds of maroon or green shale. Although separated by a disconformity representing a hiatus of long temporal duration, the two formations cannot be distinguished with certainty where geologic control consists of water-well cuttings alone. The thickness of the Ironton and Galesville Sandstones beneath the study area is between 45 and $77 \mathrm{ft}$ (table 1).

The Eau Claire Formation is of Late Cambrian age. The upper one-third to one-fourth of the formation consists of feldspathic sandstone that is light gray to yellow gray, very fine to fine grained, finely laminated to ripple cross-laminated, and slightly glauconitic; it is interlayered with scattered, thin partings of gray-green shale.

The lower part of the Franconia Formation is a confining unit, whereas the upper part is an aquifer in much of the Twin Cities metropolitan area (Runkel and others, 2003, p. 46). The Eau Claire Formation is a confining unit (Runkel and others, 2003, p. 38). The Franconia and Eau Claire Formations were considered to be confining units for the Ironton and Galesville Sandstones in the aquifer test described in this report. 
Observation well 1

Production well

Observation well 2

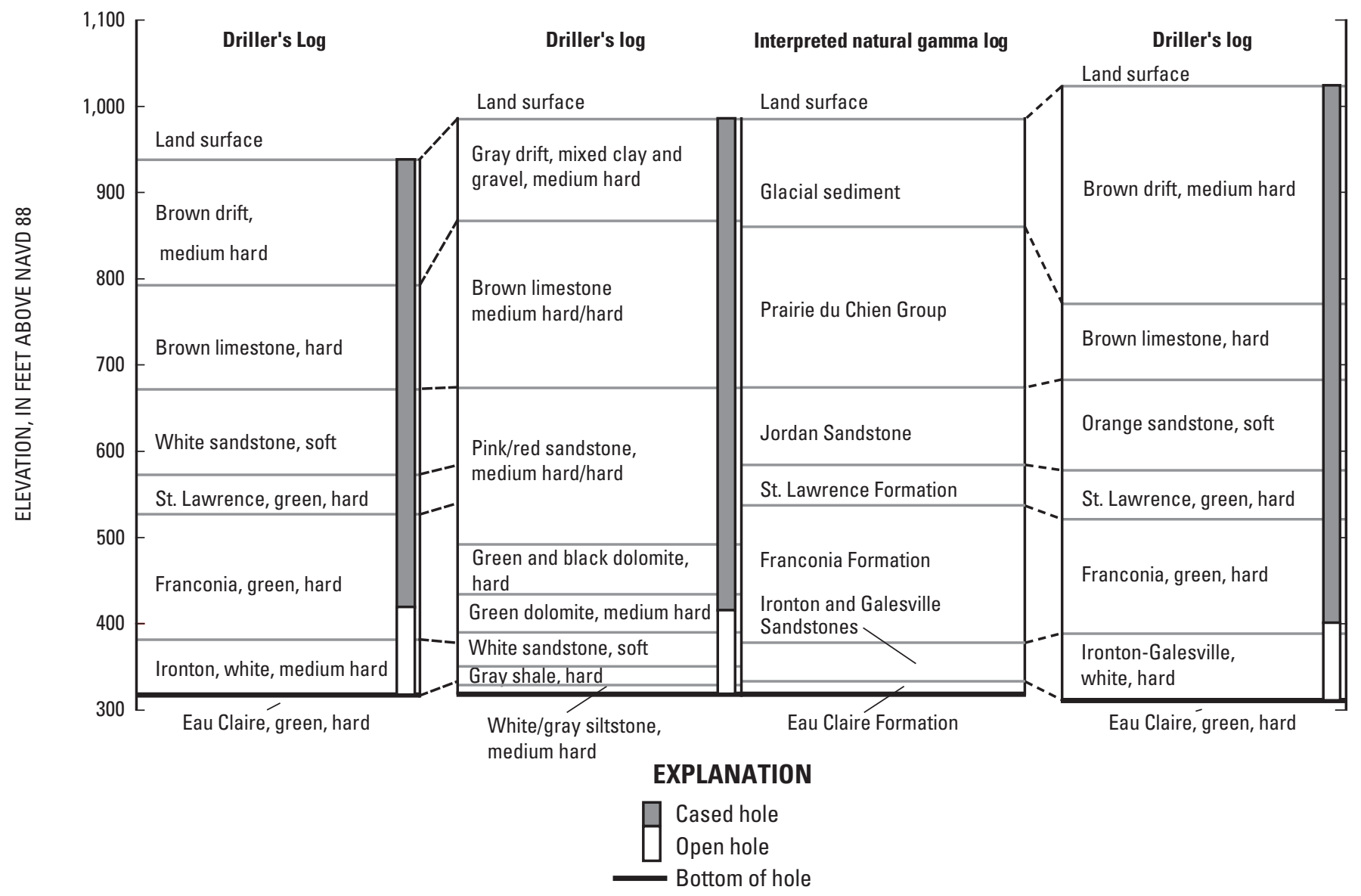

Figure 2. Lithology beneath production well and two observation wells. Natural gamma log made March 16, 1998, by Summit Envirosolutions, Inc., Minneapolis, Minnesota. Interpretation of natural gamma log by Summit Envirosolutions, Inc. Data provided by Scott Walz, Shakopee Mdewakanton Sioux Community, written commun., 2004.

\section{Previous Hydraulic Investigations}

Packer tests were used to determine the hydraulic properties of the Franconia Formation and the Ironton and Galesville Sandstones at the Aquifer Thermal Energy Storage (ATES) site in St. Paul, Minnesota, about 22 mi northeast of the study area (fig. 1). Analysis of results of the packer tests indicated two hydraulic zones within the Franconia Formation and two hydraulic zones in the Ironton and Galesville Sandstones, two of which act as a single aquifer (Runkel and others, 2003, p. 41). An aquifer test at the ATES site was used to determine that the transmissivity of the Ironton and Galesville Sandstones was approximately $690 \mathrm{ft}^{2} / \mathrm{d}$, and the storage coefficient was approximately $2.4 \times 10^{-5}$ (Miller and Delin, 1993, p. A8-A9). The vertical-to-horizontal hydraulic conductivity ratio for the Ironton and Galesville Sandstones was determined by Miller and Delin (1993) to be 0.1 .

Barr Engineering (Edina, Minnesota) constructed a ground-water flow model for the vicinity of the study area in 2004 (Scott Walz, Shakopee Mdewakanton Sioux
Community, written commun., 2004). Barr Engineering estimated the horizontal hydraulic conductivity for the layer representing the Franconia Formation and the Ironton and Galesville Sandstones using the results of a 7-day aquifer test conducted in 1999 on the city of Savage well in the FranconiaIronton-Galesville aquifer. The horizontal hydraulic conductivity estimated for this layer was $6.6 \mathrm{ft} / \mathrm{d}$, and the estimated storage coefficient was $0.4 \times 10^{-6}$.

\section{Aquifer Test}

A production (pumped) well and two observation wells were used in the aquifer test described in this report (fig. 1). The production well is cased with a 20 -in. diameter steel casing to a depth of $179 \mathrm{ft}$ and a 16-in. diameter steel casing from 170 to $570 \mathrm{ft}$. The casing ends about $25 \mathrm{ft}$ above the bottom of the Franconia Formation. The production well is an open hole from a depth of 570 to $667 \mathrm{ft}$ (table 1; fig. 2). The open hole 
Table 1. Driller's log and interpreted natural gamma borehole log of production well and driller's logs of two observation wells, Shakopee Mdewakanton Sioux Community, southeastern Minnesota.

[Natural gamma log made March 16, 1998, by Summit Envirosolutions, Inc. (Minneapolis, Minnesota). Interpretation of natural gamma log by Summit Envirosolutions, Inc. Data provided by Scott Walz, written commun., Shakopee Mdewakanton Sioux Community, 2004. NAVD 88, North American Vertical Datum of 1988]

\begin{tabular}{|c|c|c|c|}
\hline $\begin{array}{l}\text { Thickness } \\
\text { (feet) }\end{array}$ & $\begin{array}{l}\text { Depth interval } \\
\text { (feet) }\end{array}$ & $\begin{array}{c}\text { Range in eleva- } \\
\text { tion above NAVD } \\
88 \text { (feet) }\end{array}$ & Formation \\
\hline \multicolumn{4}{|c|}{ Driller's log of production well } \\
\hline 168 & $0-168$ & $982-814$ & Gray drift, mixed clay and gravel, medium hard \\
\hline 144 & $168-312$ & $814-670$ & Brown limestone, medium hard/hard \\
\hline 181 & $312-493$ & $670-489$ & Pink/red sandstone, medium hard/hard \\
\hline 58 & $493-551$ & $489-431$ & Green and black dolomite, hard \\
\hline 44 & $551-595$ & $431-387$ & Green dolomite, medium hard \\
\hline 40 & $595-635$ & $387-347$ & White sandstone, soft \\
\hline 21 & $635-656$ & $347-326$ & Gray shale, hard \\
\hline \multirow[t]{2}{*}{11} & $656-667$ & $326-315$ & White/gray siltstone, medium hard. \\
\hline & & & Bottom of hole is 667 feet below land surface \\
\hline \multicolumn{4}{|c|}{ Interpreted natural gamma log of production well } \\
\hline 125 & $0-125$ & $982-857$ & Glacial sediments \\
\hline 186 & $125-311$ & $857-671$ & Prairie du Chien Group \\
\hline 90 & $311-401$ & $671-581$ & Jordan Sandstone \\
\hline 47 & $401-448$ & $581-534$ & St. Lawrence Formation \\
\hline 159 & $448-607$ & $53-375$ & Franconia Formation \\
\hline 45 & $607-652$ & $375-330$ & Ironton and Galesville Sandstones \\
\hline \multirow[t]{2}{*}{15} & $652-667$ & $330-315$ & Eau Claire Formation \\
\hline & & & Bottom of hole is 667 feet below land surface \\
\hline \multicolumn{4}{|c|}{ Driller's log of observation well 1} \\
\hline 145 & $0-145$ & $937-792$ & Brown drift, medium hard \\
\hline 120 & $145-265$ & $792-672$ & Brown limestone, hard \\
\hline 100 & $265-365$ & $672-572$ & White sandstone, soft \\
\hline 45 & $365-410$ & $572-527$ & St. Lawrence, green, hard \\
\hline 145 & $410-555$ & $527-382$ & Franconia, green, hard \\
\hline \multirow[t]{3}{*}{65} & $555-620$ & $382-317$ & Ironton, white, medium hard \\
\hline & 620 & 317 & Eau Claire, green, hard \\
\hline & & & Bottom of hole is 620 feet below land surface \\
\hline \multicolumn{4}{|c|}{ Driller's log of observation well 2} \\
\hline 252 & $0-252$ & $1,023-771$ & Brown drift, medium hard \\
\hline 88 & $252-340$ & $771-683$ & Brown limestone, hard \\
\hline 105 & $340-445$ & $683-578$ & Orange sandstone, soft \\
\hline 57 & $445-502$ & $578-521$ & St. Lawrence, green, hard \\
\hline 133 & $502-635$ & $521-388$ & Franconia, green, hard \\
\hline \multirow[t]{3}{*}{77} & $635-712$ & $388-311$ & Ironton-Galesville, white, hard \\
\hline & 712 & 311 & Eau Claire, green, hard \\
\hline & & & Bottom of hole is 712 feet below land surface \\
\hline
\end{tabular}


was enlarged by blasting and removing sand and sandstone to form a chamber at least $20 \mathrm{ft}$ across (Stan Ellison, Shakopee Mdewakanton Sioux Community, oral commun., 2004). The pump is set inside the casing. The bottom of the pump is at a depth of $465 \mathrm{ft}$. The production well was not pumped between September 17 and December 6, 2004, which was the beginning date for the aquifer test.

Observation well 1 is 3,247 ft northwest of the production well. The well is cased with an 8-in. diameter steel casing from 0 to $145 \mathrm{ft}$ and 4-in. diameter casing from 145 to $520 \mathrm{ft}$. The well is a 4-in. diameter open hole from 520 to $620 \mathrm{ft}$. Observation well 2 is 3,049 ft southeast of the production well. The well is cased with 8-in. diameter steel casing from 0 to $252 \mathrm{ft}$ and with a 4 -in. diameter steel casing from 252 to $623 \mathrm{ft}$. The well is a 4-in. diameter open hole from 623 to $712 \mathrm{ft}$. Both observation wells were cased to about the same elevation as the production well (fig. 2) so that they were all open to the same formations.

Water levels in the production well were recorded every 10 seconds during the aquifer test with a transducer that is part of the Shakopee Community's monitoring system. The depth of the transducer below land surface was not known, and drawdown and recovery water levels in the well were measured from an arbitrary datum. The transducer appeared to have moved about the time recovery began; the recorded water levels at the end of recovery were about $8 \mathrm{ft}$ higher than at the beginning of the aquifer test (fig. 3A, table A1 in appendix). Water levels in the production well also were measured manually with an electric tape for 1 hour at 1 - to 5-minute intervals after the pump was shut off (fig. $3 B$, table A2 in appendix). The depth to water was measured from the measuring point at the top of the well, which is $985.02 \mathrm{ft}$ above NAVD 88. A comparison of the water levels measured with an electric tape and those recorded by the transducer is shown in figure $3 C$.

Pressure transducers also were used to record changes in water levels in the observation wells (fig. 4, table A3). The pressure of the water above the transducer was measured and recorded every 90 seconds or when the pressure changed by $0.004 \mathrm{lb} / \mathrm{in}^{2}$ (an approximate 0.01 -ft change in water level). Manual measurements of the water depth below the top of the well casing were made using an electric tape during the aquifer test and during recovery. These measurements were used to convert the measured pressures to water-level elevations in the wells.

Background water levels were measured before the beginning of the aquifer test in both observation wells (fig. 5). These measurements show that the potentiometric surface in the aquifer increased by about $1 \mathrm{ft}$ in the week prior to the beginning of the test.

Barometric pressure was measured at a weather station maintained by the Shakopee Community adjacent to observation well 1. The recorded barometric pressure is shown in figures 5 and 6 . The barometric efficiency of both observation wells was computed from the water levels measured before the beginning of the aquifer test. The barometric efficiency $(B)$ of a well is defined as:

$$
B=\frac{\gamma \Delta h}{\Delta p_{a}}
$$

where $\gamma$ is the specific weight of water $\left(62.409 \mathrm{lb} / \mathrm{ft}^{3}\right.$ at $50{ }^{\circ} \mathrm{F}$, the approximate temperature of the water in the Ironton and Galesville Sandstones); $\Delta h$ is the change in water level in the well; and $\Delta p_{a}$ is the change in atmospheric pressure (Todd, 1980, p. 236). The barometric efficiencies of observation wells 1 and 2 were estimated to be -0.52 and -0.34 , respectively. The expected water-level changes caused by barometric pressure changes are shown in figure 6 . The largest expected change in water level was about $1 \mathrm{ft}$ for both wells. Consequently, the measured water levels in the observation wells during the test were not adjusted for changes in atmospheric pressure because the measured changes were greater than $33 \mathrm{ft}$, which is much greater than the 1-ft change in water level caused by changing atmospheric pressure.

The discharge from the production well pump was measured by a discharge meter that recorded the number of gallons pumped. The pumping rate in gallons per minute (gal/min) was determined by dividing the gallons pumped over 6 minutes by 6 . Pumping rates measured by this method are listed in table 2. The discharge from the pump was not regulated; the pump operated at its greatest output. Therefore, when the water level in the production well declined, the output of the pump decreased. Average discharge during the aquifer test was $610 \mathrm{gal} / \mathrm{min}$. The water pumped from the well was discharged to a wetland about $430 \mathrm{ft}$ from the well. The discharged water did not infiltrate to the pumped aquifer because of the intervening confining units (fig. 2) and was assumed not to affect the measured water levels during the test.

The aquifer test began at 10:30 a.m. on December 6, 2004. The pump was shut off December 9 at 3:26 p.m. The pump was turned on briefly December 13 as indicated by the drawdown spike in figure 3 . The recorded and measured water levels for the production well are presented in tables A1 and A2 in the appendix and are shown in figure 3. Drawdowns for the pumped well and observation wells were used in the analyses of aquifer properties. However, the measured recovery for the production well was not used in the analyses of aquifer properties because the transducer seemed to have moved when the pump was turned off on December 9 and when it was turned on briefly on December 13. Drawdown and recovery were recorded in both observation wells from December 6-22, 2004. The recorded drawdown and recovery for both observation wells are given in table A3 of the appendix and are shown in figure 4.

The cities of Prior Lake, Savage, and Shakopee, Minnesota (fig. 1), also withdraw water from wells screened in the Ironton and Galesville Sandstones. Pumpage in these wells may affect the water levels in the two observation wells used for this aquifer study (Jay Frischman, Minnesota Department of Natural Resources, written commun., 2005). However, the 

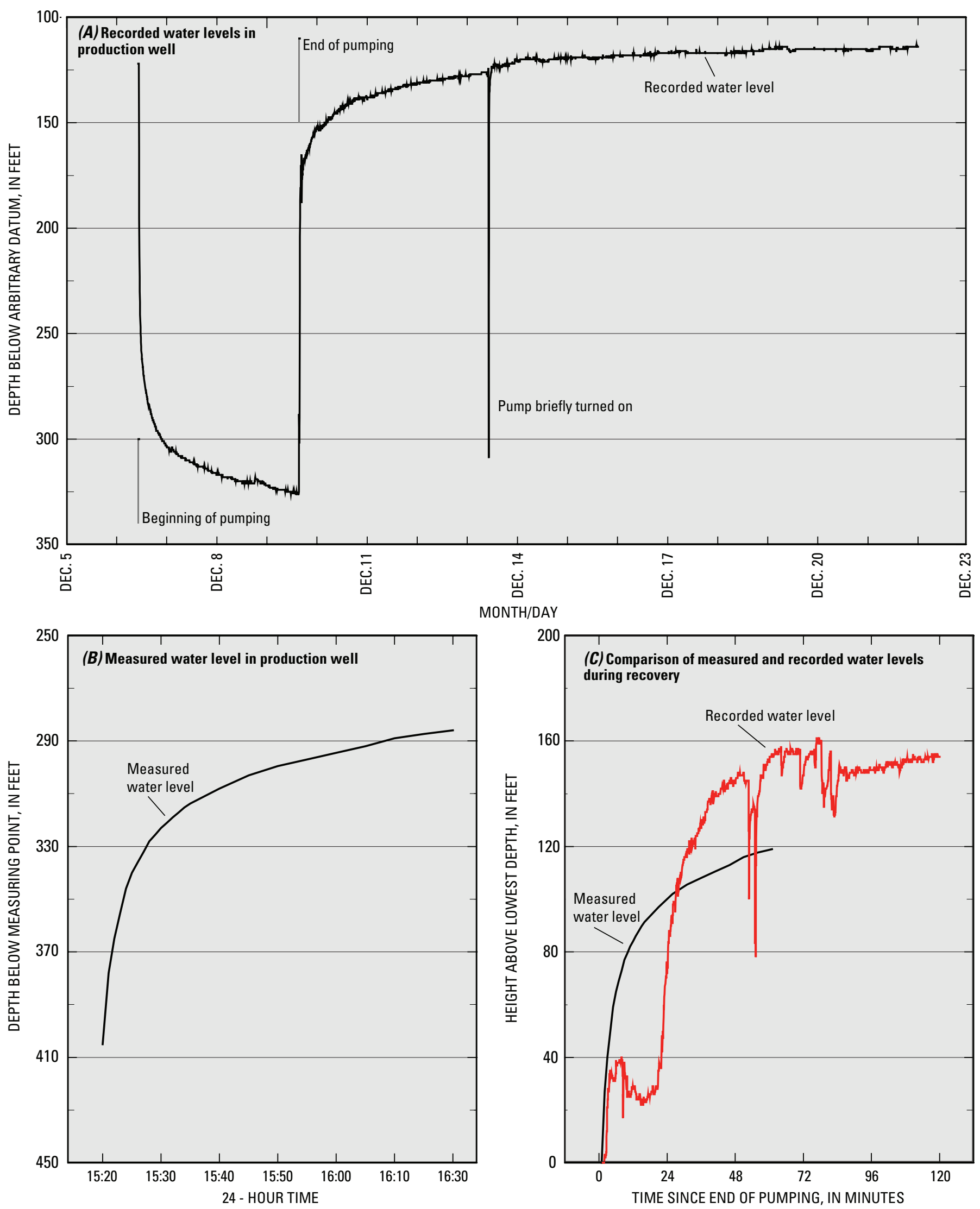

Figure 3. (A) Recorded water levels during aquifer test for production well, December 6-22, 2004, (B) measured water levels in production well, December 9, 2004, and (C) comparison of measured and recorded water levels during production well recovery, December 9 , 2004. 


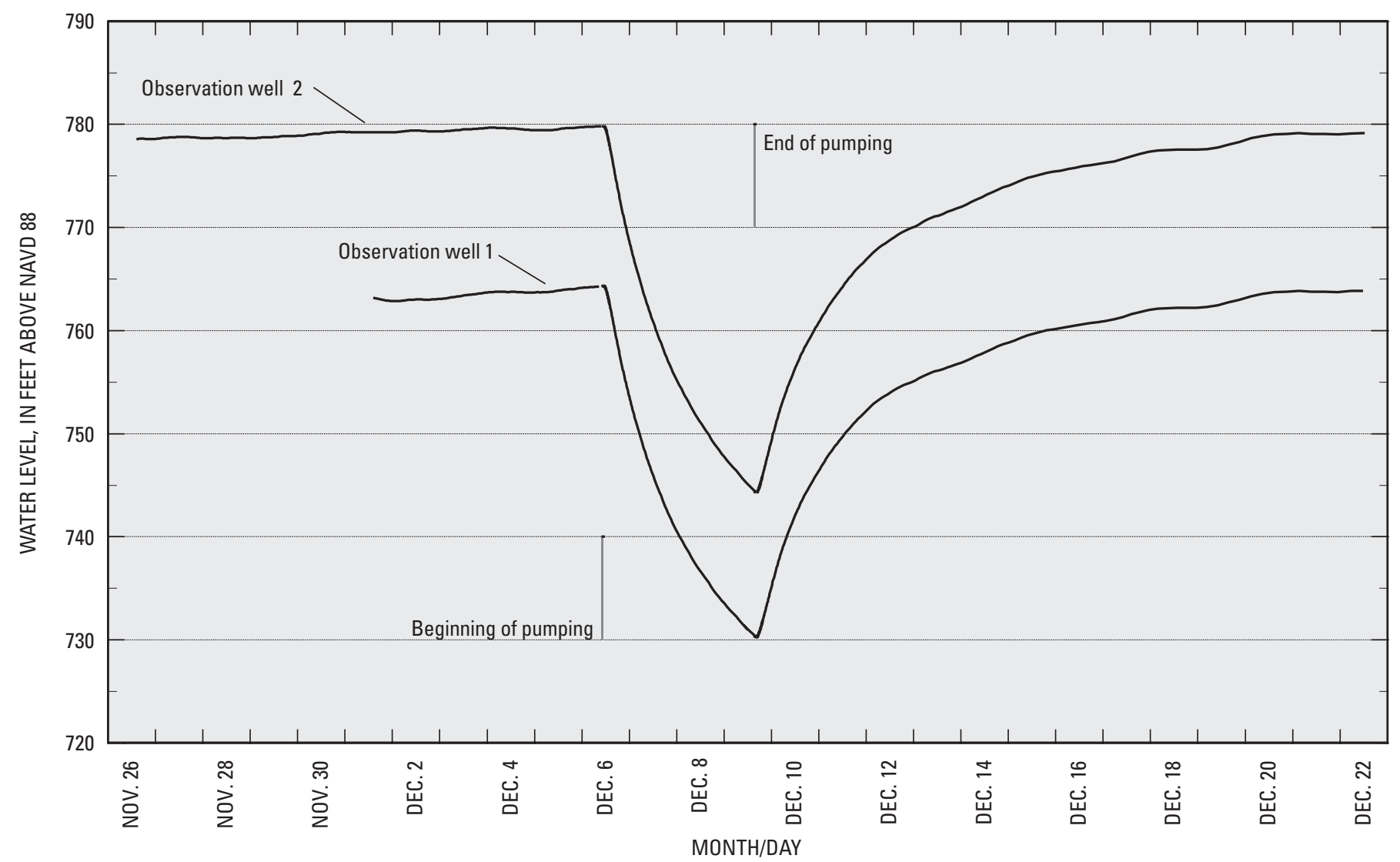

Figure 4. Recorded water levels in observation wells 1 and 2, November 26-December 22, 2004.

wells in these nearby communities were not pumped during the aquifer test (Lanya Ross, Shakopee Mdewakanton Sioux Community, oral commun., 2005).

\section{Aquifer-Test Analysis and Hydraulic Properties of the Ironton and Galesville Sandstones}

Four curve-fitting methods and two graphical methods were used to estimate the transmissivity and storage coefficient of the Ironton and Galesville Sandstones. The commercial software AQTESOLV (HydroSOLVE, 2000) was used to apply the six methods to the data collected during the aquifer test. The four curve-fitting methods were the Theis, Hantush, Hantush-Jacob, and Neumann-Witherspoon methods. These methods were applied to the drawdown and residual recovery curves of the observation wells. The two graphical methods were the Cooper-Jacob method and the Theis recovery method. The Cooper-Jacob method was applied to the drawdown curve of the production well and the drawdown curves of the two observation wells. The Theis recovery method was applied to the residual drawdown curves of the two observation wells.
All six methods were developed for very specific aquifer and ground-water flow conditions. The following conditions apply for all six methods (HydroSOLVE, 2000): (1) the aquifer has infinite areal extent, (2) the aquifer is homogenous, isotropic, and of uniform thickness, (3) the flow is unsteady, (4) water is released instantaneously from storage with decline of hydraulic head, and (5) the diameter of the pumped well is very small so that storage in the well can be neglected. The Theis, Cooper-Jacob, and Theis recovery methods were developed for confined aquifers that are not leaky; that is, water does not pass through the confining layers into the aquifer. The Hantush, Hantush-Jacob, and Neumann-Witherspoon methods were developed for leaky aquifers; that is, water moves through the confining layers into the aquifer from aquifers above or below it. Additional conditions for the use of the methods are mentioned in the discussion for each method.

The Theis (Ferris and others, 1962; Todd, 1980; HydroSOLVE, 2000), Hantush (Hantush, 1960; HydroSOLVE, 2000), Hantush and Jacob (Hantush and Jacob, 1955; HydroSOLVE, 2000), and Neuman-Witherspoon (Neuman and Witherspoon, 1969; HydroSOLVE, 2000) methods were applied to the drawdown and recovery data for the two observation wells. The equations for each method are discussed briefly in following paragraphs.

Additional conditions necessary for use of the Theis method (HydroSOLVE, 2000) are: (1) the pumped well is 


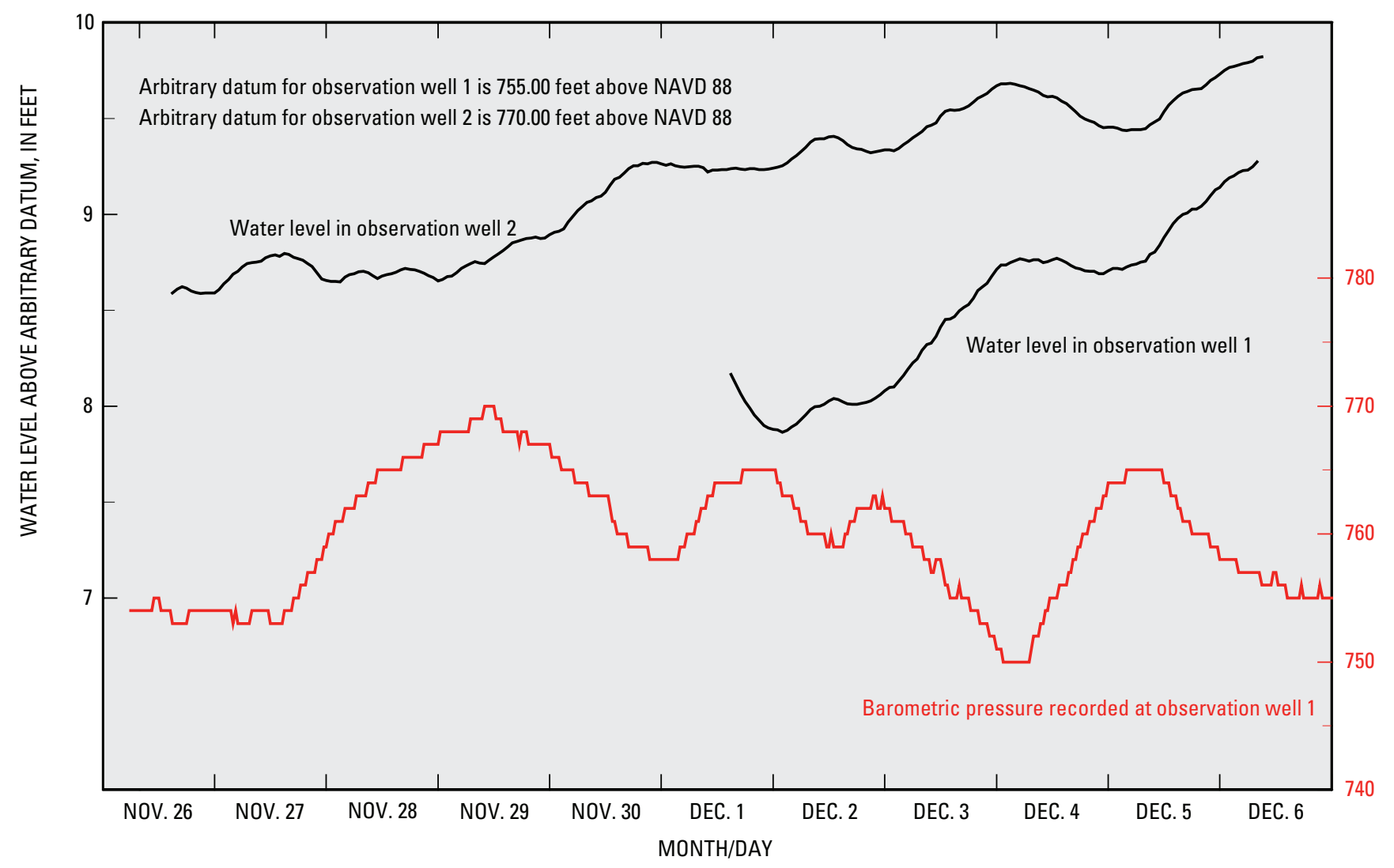

Figure 5. Recorded water levels in observation wells 1 and 2 and recorded barometric pressure at observation well 1 before aquifer test, November 26-December 6, 2004.

fully or partially penetrating, (2) flow to the pumped well is horizontal when the pumped well fully penetrates the aquifer, and (3) the aquifer is confined. The Theis method relates the drawdown $(s)$ observed in a well as a result of pumping from another well at a discharge $(Q)$ to the transmissivity $(T)$ and storage coefficient $(S)$ of an aquifer by the following equation:

$$
s=\left(\frac{Q}{4 \pi T}\right) W(u),
$$

where $W(u)$, termed the well function, is a convenient symbolic form of the following integral:

$$
\int_{u}^{\infty} \frac{e^{-u} d u}{u}
$$

where

$$
u=\frac{r^{2} S}{4 T t},
$$

$r$ is the radial distance from the pumped well, and $t$ is the time since beginning of pumping (Todd, 1980, p. 123). The integral can be expanded as a convergent series (Todd, 1980, p. 124):

$$
-0.5772-\ln u+u-\frac{u^{2}}{2 \cdot 2 !}+\frac{u^{3}}{3 \cdot 3 !}-\frac{u^{4}}{4 \cdot 4 !}+\ldots .
$$

Additional conditions necessary for use of the Hantush method are (HydroSOLVE, 2000): (1) the aquifer potentiometric surface is initially horizontal, (2) the pumped well fully or partially penetrates the aquifer, (3) flow to the pumped well is horizontal when the pumped well fully penetrates the aquifer, (4) the aquifer is leaky, (5) the confining bed(s) has infinite areal extent, uniform vertical hydraulic conductivity and storage coefficient, and uniform thickness, (6) confining bed(s) has uniform storage coefficient, (7) confining bed(s) is overlain or underlain by an infinite constant-head plane source, and (8) the flow in the confining bed(s) is vertical.

The drawdown curve given by Hantush (Hantush, 1960; HydroSOLVE, 2000) is

$$
s=\frac{Q}{4 \pi T} \int_{u}^{\infty} \frac{e^{-y}}{y} \operatorname{erfc} \frac{\beta \sqrt{u}}{\sqrt{y(y-u)}} d y,
$$

where

$$
u=\frac{r^{2} S}{4 T t} ; \text { and }
$$




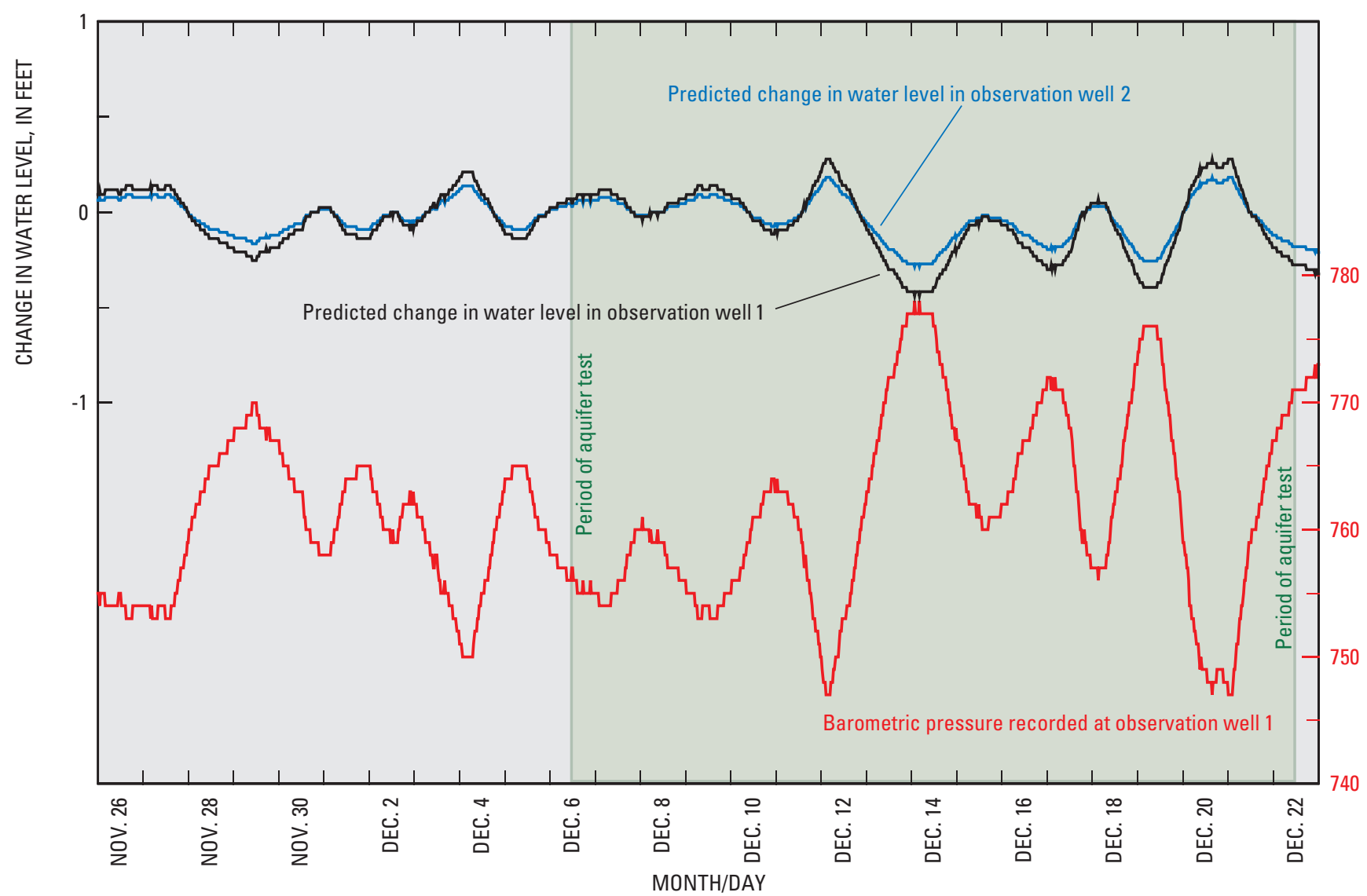

Figure 6. Predicted changes in water levels in observation wells 1 and 2 due to changes in barometric pressure during aquifer test, November 26-December 22, 2004.

$$
\beta=\frac{r}{4}\left[\sqrt{\frac{K^{\prime} / b^{\prime}}{T} \frac{S^{\prime}}{S}}+\sqrt{\frac{K^{\prime \prime} / b^{\prime \prime}}{T} \frac{S^{\prime \prime}}{S}}\right],
$$

where $y$ is the variable of integration;

$b^{\prime}, b^{\prime \prime}$ are the thickness of the confining layers;

$\mathrm{K}^{\prime}, \mathrm{K}^{\prime \prime}$ are the vertical hydraulic conductivities of the confining layers;

$S^{\prime}, S^{\prime \prime}$ are the storage coefficients of the confining layers; and all other terms as previously defined.

Additional conditions necessary for use of the HantushJacob method are (HydroSOLVE, 2000): (1) the aquifer potentiometric surface is initially horizontal, (2) pumped well fully or partially penetrates the aquifer, (3) the aquifer is leaky, (4) the confining bed(s) has infinite areal extent, uniform vertical hydraulic conductivity, and uniform thickness, (5) confining bed(s) is overlain or underlain by an infinite constanthead plane source, and (6) the flow in the confining bed(s) is vertical. is:

The drawdown curve given by Hantush and Jacob (1955)

$$
s=\frac{Q}{4 \pi T} w(u, r / B)
$$

where $\mathrm{w}(u, r / B)$ is the Hantush function for leaky aquifers;

$$
\int_{u}^{\infty} \frac{e^{-y-r^{2} / 4 B^{2} y}}{y} d y
$$

and

$$
\begin{gathered}
u=\frac{r^{2} S}{4 T t} ; \\
B=\sqrt{\frac{T b^{\prime}}{K^{\prime}}} ; \text { and }
\end{gathered}
$$

all other terms as previously defined.

Additional conditions necessary for use of the Neumann-Witherspoon method are (HydroSOLVE, 2000): (1) the aquifer potentiometric surface is initially horizontal, (2) the pumped well fully penetrates the aquifer, (3) flow to the pumped well is horizontal, (4) the aquifer is leaky, (5) the confining bed(s) has infinite areal extent, uniform vertical hydraulic conductivity, uniform storage coefficient, and uniform thickness, (6) confining bed(s) has uniform storage coefficient (7) confining bed(s) is overlain or underlain by an 
Table 2. Measured pumping rate from production well, Shakopee Mdewakanton Sioux Community, southeastern Minnesota, December 6-9, 2004.

[gal/min, gallons per minute]

\begin{tabular}{|c|c|}
\hline $\begin{array}{l}\text { Time from start of } \\
\text { pumping (hours) }\end{array}$ & $\begin{array}{c}\text { Measured pumping rate } \\
\text { (gal/min) }\end{array}$ \\
\hline 1 & 644.5 \\
\hline 2 & 637.0 \\
\hline 3 & 630.0 \\
\hline 4 & 630.0 \\
\hline 5 & 627.0 \\
\hline 21 & 612.0 \\
\hline 22 & 613.0 \\
\hline 23 & 611.0 \\
\hline 24 & 611.0 \\
\hline 25 & 609.4 \\
\hline 26 & 610.0 \\
\hline 28 & 609.8 \\
\hline 29 & 609.2 \\
\hline 45 & 604.4 \\
\hline 46 & 604.4 \\
\hline 49 & 603.8 \\
\hline 50 & 603.2 \\
\hline 53 & 602.2 \\
\hline 54 & 603.0 \\
\hline 69 & 600.0 \\
\hline 70 & 599.8 \\
\hline 72.75 & 599.2 \\
\hline Average & 610 \\
\hline
\end{tabular}

infinite constant-head plane source, and (8) the flow in the confining bed(s) is vertical.

The drawdown equation given by Neuman and Witherspoon (Neuman and Witherspoon, 1969; HydroSOLVE, 2000) is:

$$
\begin{aligned}
& s=\frac{Q}{4 \pi T} \int_{0}^{\infty}\left(1-e^{-y \bar{t}_{D 1}}\right)\left([1+G(y)] J_{o}\left[\omega_{1}(y)\right]+\right. \\
& \left.[1-G(y)] J_{o}\left[\omega_{2}(y)\right]\right) \frac{d y}{y}
\end{aligned}
$$

where

$b_{i}$ is the thickness of $\mathrm{i}^{\text {th }}$ aquifer; $b_{j}$ is thickness of $\mathrm{j}^{\text {th }}$ confining layer;

$\mathrm{K}_{i}$ is permeability of the $\mathrm{i}^{\text {th }}$ aquifer;

$\mathrm{K}_{j}$ is permeability of the $\mathrm{j}^{\text {th }}$ aquifer;

$\mathrm{S}_{i}$ is specific storage for the $\mathrm{i}^{\text {th }}$ aquifer;

$\mathrm{S}_{j}$ is specific storage for the $\mathrm{j}^{\text {th }}$ confining layer;

$$
t_{D i}=\frac{K_{i} t}{S s_{i} r^{2}},
$$

dimensionless time for pumped $\left(i^{\text {th }}\right)$ aquifer;

$$
\begin{gathered}
\bar{t}_{D 1}=\frac{t_{D 1}\left(\frac{r}{B_{11}}\right)^{4}}{\left(4 \beta_{11}\right)^{2}} ; \\
\frac{r}{B_{i j}}=r \sqrt{\frac{K_{j}^{\prime}}{T_{i} b_{j}^{\prime}}},
\end{gathered}
$$

$r / B_{11}$ refers to the pumped aquifer, $r / B_{21}$ refers to the unpumped aquifer;

$$
\beta_{i j}=\frac{r}{4 b_{i} \sqrt{\frac{K^{\prime} j S^{\prime} s j}{K_{i} S_{s i}}}} ;
$$

$\beta_{11}$ refers to the pumped aquifer, $\beta_{21}$ refers to the unpumped aquifer;

$$
\begin{gathered}
G(y)=\frac{M(y)}{F(y)} ; \\
\omega_{1}^{2}(y)=\frac{1}{2}[N(y)+F(y)] ; \\
G(y)=\frac{M(y)}{F(y)} ;
\end{gathered}
$$

$$
F^{2}(y)=M^{2}(y)+\left[\frac{2\left(\frac{r}{B_{11}}\right)\left(\frac{r}{B_{21}}\right) y}{\sin y}\right]^{2} ;
$$




$$
\begin{gathered}
M(y)=\left[\frac{\left(\frac{r}{B_{11}}\right)^{4}}{\left(4 \beta_{11}\right)^{2}}-\frac{\left(\frac{r}{B_{21}}\right)^{4}}{\left(4 \beta_{21}\right)^{2}} y^{2}-\right. \\
{\left[\left(\frac{r}{B_{11}}\right)-\left(\frac{r}{B_{21}}\right)^{2}\right] y \cot y ;}
\end{gathered}
$$

and all other terms are as previously defined. The fitted curves and recorded data are shown in figures 7 and 8 , and the estimated aquifer transmissivities and storage coefficients are given in table 3 .

The Cooper-Jacob method (Todd, 1980, p. 129-130) was applied to the drawdown curves of the production well and the two observation wells. The Theis recovery method (Ferris and others, 1962, p. 100-102; Jacob, 1963, p. 283; Todd, 1980, p. 131-133) was applied to the residual drawdown curves of the two observation wells.

Additional conditions necessary for use of the CooperJacob method are (HydroSOLVE, 2000): (1) aquifer potentiometric surface is initially horizontal, (2) the pumped well fully penetrates the aquifer, (3) flow to the pumped well is horizontal, (4) the aquifer is confined, and (5) values of $u$ are small.

The Cooper-Jacob method is derived from the Theis equation for unsteady radial flow in a confined aquifer (Todd, 1980, p. 129). In this method a straight line is fitted to the straight portion of the drawdown curve plotted on semilogarithmic paper. The drawdown across one log cycle $\left(s_{10}\right)$ is determined, and the transmissivity $(T)$ and storage coefficient $(S)$ are determined from the following two equations:

$$
S=\frac{2.25 T t_{o}}{r^{2}},
$$

and

$$
T=\frac{2.30 Q}{4 \pi s_{10}}
$$

where $t_{0}$ is the point where the fitted line crosses the time axis (the drawdown, $s$, is 0 ), $r$ is the distance from the pumped well, and $Q$ is the pumping rate. This method can be used when

$$
u=\frac{r^{2} S}{4 T t} \leq 0.05
$$

(Heath, 1983).

The Cooper-Jacob method was applied to the drawdown record of the production well and the two observation wells (fig. 9). The storage coefficient was not computed for the production well because it is dependent on the radius of the production well chamber, which is not known. The value of $u$ ranges from 0.06 to 0.24 for the observation wells and is less than $1 \times 10^{-5}$ for the production well. The estimated aquifer transmissivities and storage coefficients are given in table 3 .

The Theis recovery method is derived from the fact that if a well is pumped for a known period of time and then shut down and allowed to recover, the residual drawdown at any instant will be the same as if the discharge of the well had been continued and a recharge well with the same flow had been introduced at the same point at the instant the discharge stopped. The residual drawdown is the difference between the observed water level and the water level before pumping began. The residual water level is plotted on a semilogarithmic plot against $\frac{t}{t^{\prime}}$, where $t$ is the time since the aquifer test began and $t^{\prime}$ is the time since the pump was shut off (Todd, 1980, p. 133). A straight line is fitted to the straight portion of the curve, and the residual drawdown per log cycle $\left(\Delta s^{\prime}\right)$ is determined. The transmissivity is determined from:

$$
T=\frac{2.30 Q}{4 \pi \Delta s^{\prime}} .
$$

The storage coefficient cannot be estimated using the Theis recovery method.

AQTESOLV was used to solve the Theis recovery method. It solves for a slightly different equation (HydroSOLVE, 2000):

$$
s^{\prime \prime}=\frac{Q}{4 \pi T}\left[\ln \left(\frac{t}{t^{\prime}}\right)-\ln \left(S_{r}\right)\right],
$$

where $s^{\prime \prime}$ is the residual displacement, and $S_{r}$ is the ratio of storativity during pumping to storativity during recovery Equation 27 can be transformed into equation 26 if $\log _{10}$ is used instead of the natural $\log$ and the $s^{\prime \prime}$ is selected a log cycle apart. $S_{r}$ is determined by where the straight line intercepts the $\log _{10}\left(t / t^{\prime}\right)$ axis. The value of $S_{r}$ should be about 1 if there are no boundary effects (HydroSOLVE, 2000). If $S_{r}>1$, there is indication of a recharge boundary during the aquifer test; $S_{r}<1$ suggests the presence of a barrier or no-flow boundary (HydroSOLVE, 2000).

The Theis recovery method was applied to the residual drawdown data for both observation wells (fig. 10). The estimated transmissivities are shown in table 3.

The transmissivity estimated using the six methods ranged from 450 to $650 \mathrm{ft}^{2} / \mathrm{d}$ (table 3 ). As shown in table 3 , the average transmissivity for the fitted methods (Theis, Hantush, Hantush-Jacob, and Neuman-Witherspoon) was $510 \mathrm{ft}^{2} / \mathrm{d}$; the average transmissivity for the Cooper-Jacob and Theis recovery graphical methods was $600 \mathrm{ft}^{2} / \mathrm{d}$; and the average transmissivity for all six methods was $540 \mathrm{ft}^{2} / \mathrm{d}$. The average transmissivity for the three methods developed for nonleaky aquifers, Theis, Cooper-Jacob, and Theis recovery, was $590 \mathrm{ft}^{2} / \mathrm{d}$. The 


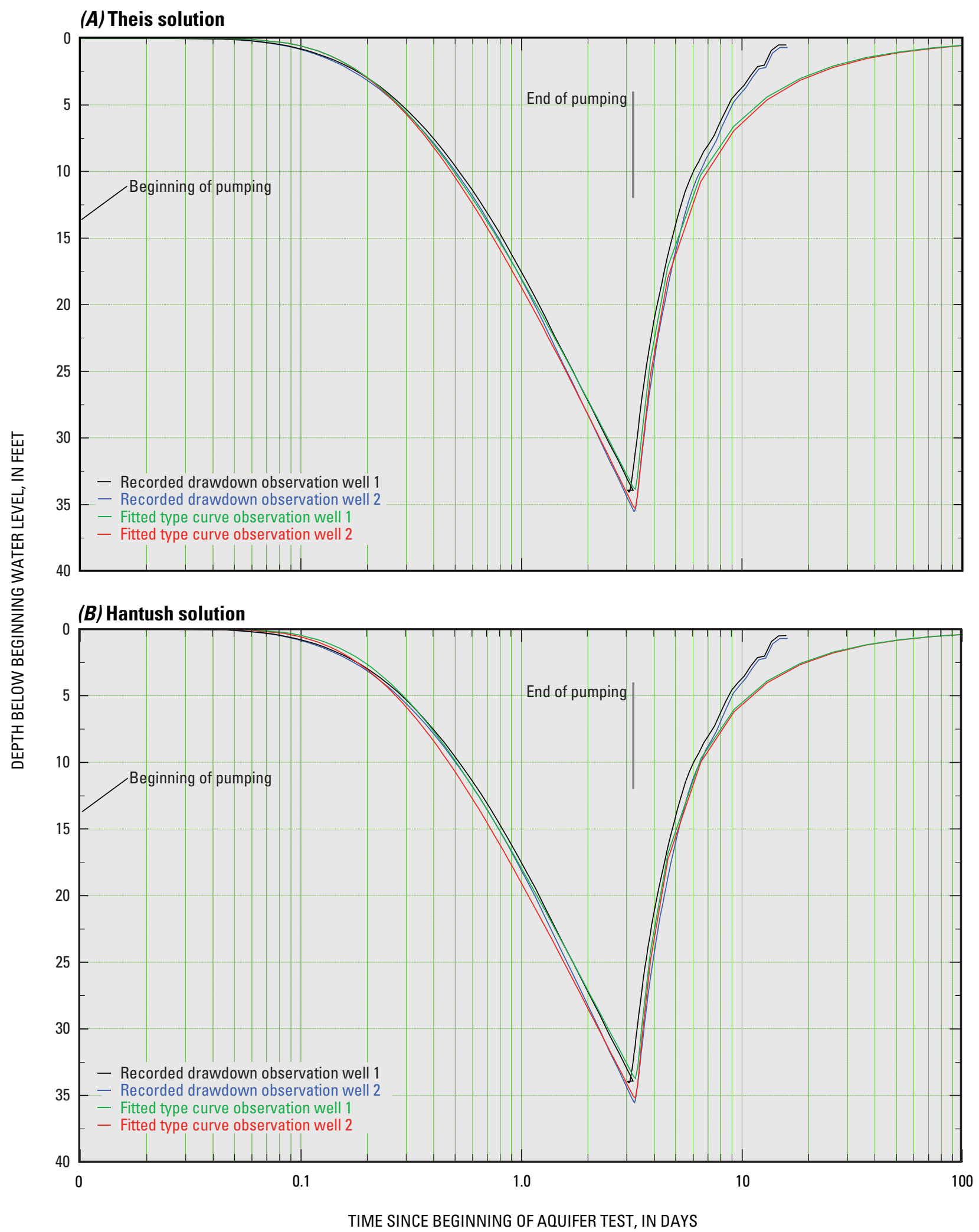

Figure 7. (A) Theis and (B) Hantush fitted type curves and recorded water levels for observation wells 1 and 2, December $6-$ 22, 2004. 


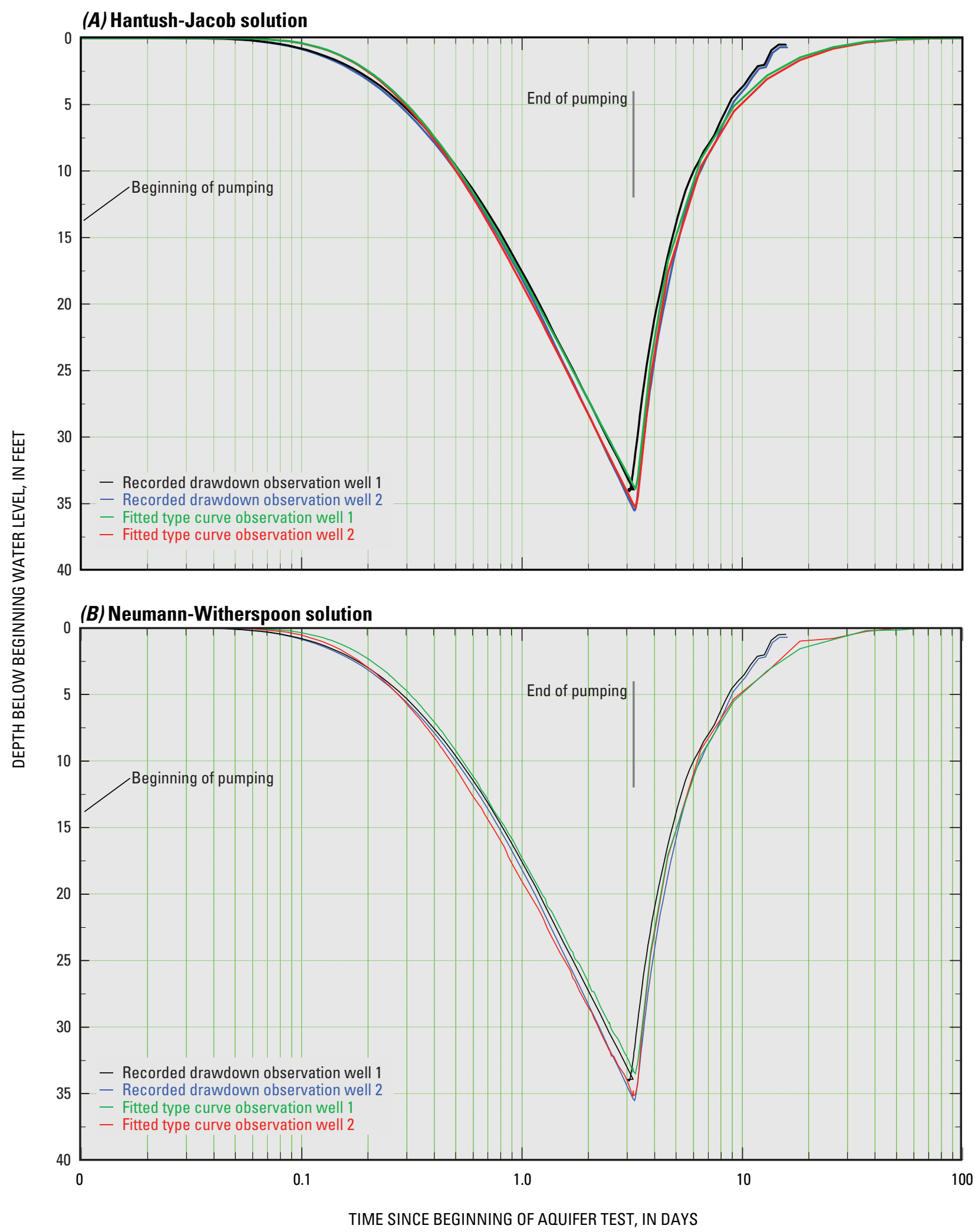

Figure 8. (A) Hantush-Jacob and (B) Neumann-Witherspoon fitted type curves and recorded water levels in observation wells 1 and 2, December 6-22, 2004. 
Table 3. Estimated aquifer properties of Ironton and Galesville Sandstones, Shakopee Mdewakanton Sioux Community, southeastern Minnesota.

$\left[S r\right.$, ratio of storativity during pumping to storativity during recovery; $r / B$, dimensionless leakage factor; $B$, leakage factor; $T^{\prime}$, vertical transmissivity in confining unit overlying aquifer; $S^{\prime}$, coefficient of storage in confining unit overlying aquifer; $K_{V} / K_{x}$, ratio of vertical hydraulic conductivity to horizontal hydraulic conductivity; $b$, thickness of aquifer; $\mathrm{ft}^{2} / \mathrm{d}$, feet squared per day; $\mathrm{ft}$, feet; $\mathrm{ft} / \mathrm{d}$, feet per day; --, not applicable]

\begin{tabular}{|c|c|c|c|c|c|c|c|c|c|c|c|}
\hline $\begin{array}{l}\text { Method } \\
\text { used to } \\
\text { estimate } \\
\text { aquifer } \\
\text { proper- } \\
\text { ties }\end{array}$ & $\begin{array}{l}\text { Well(s) for which } \\
\text { estimates were } \\
\text { made }\end{array}$ & $\begin{array}{l}\text { Trans- } \\
\text { missiv- } \\
\text { ity, T, } \\
\left(\mathrm{ft}^{2} / \mathrm{d}\right)\end{array}$ & $\begin{array}{l}\text { Storage } \\
\text { coefficient, } \\
\text { S (dimen- } \\
\text { sionless) }\end{array}$ & Sr & $r / B$ & B & $\begin{array}{c}\mathrm{T}^{\prime} \\
\left(\mathrm{ft}^{2} / \mathrm{d}\right)\end{array}$ & $\mathbf{S}^{\prime}$ & $K_{v} / K_{x}$ & $\begin{array}{c}\text { b } \\
\text { (ft) }\end{array}$ & $\begin{array}{c}\text { Hy- } \\
\text { draulic } \\
\text { conduc- } \\
\text { tivity, K } \\
\text { (ft/d) }\end{array}$ \\
\hline \multirow[t]{2}{*}{ Theis } & Observation well 1 & 590 & $5.1 \times 10-5$ & -- & -- & -- & -- & -- & 0.1 & 45 & 13.1 \\
\hline & Observation well 2 & 560 & $5.6 \times 10-5$ & -- & -- & -- & -- & -- & .1 & 45 & 12.4 \\
\hline \multirow[t]{2}{*}{ Hantush } & Observation well 1 & 450 & $4.3 \times 10-5$ & -- & -- & 0.0767 & -- & -- & .1 & 45 & 10.0 \\
\hline & Observation well 2 & 480 & $4.8 \times 10-5$ & -- & -- & .0530 & -- & -- & .1 & 45 & 10.7 \\
\hline \multirow{2}{*}{$\begin{array}{c}\text { Hantush- } \\
\text { Jacob }\end{array}$} & Observation well 1 & 520 & $5.2 \times 10-5$ & -- & 0.2319 & -- & -- & -- & .1 & 45 & 11.6 \\
\hline & Observation well 2 & 500 & $5.7 \times 10-5$ & -- & .2218 & -- & -- & -- & .1 & 45 & 11.1 \\
\hline \multirow{2}{*}{$\begin{array}{l}\text { Neuman- } \\
\text { Wither- } \\
\text { spoon }\end{array}$} & Observation well 1 & 490 & $5.0 \times 10-5$ & -- & .2496 & .0400 & $1.0 \times 10-5$ & 0.0591 & -- & -- & 10.9 \\
\hline & Observation well 2 & 490 & $5.0 \times 10-5$ & -- & .2496 & .0400 & $1.0 \times 10-5$ & .0591 & -- & -- & 10.9 \\
\hline \multicolumn{2}{|c|}{ Average fitted methods } & 510 & $5.1 \times 10-5$ & & & & & & & & 11.3 \\
\hline \multirow{3}{*}{$\begin{array}{r}\text { Cooper- } \\
\text { Jacob }\end{array}$} & Observation well 1 & 650 & $4.2 \times 10-5$ & -- & -- & -- & -- & -- & -- & -- & 14.4 \\
\hline & Observation well 2 & 620 & $4.6 \times 10-5$ & -- & -- & -- & -- & -- & -- & -- & 13.8 \\
\hline & Production well & 590 & -- & -- & -- & -- & -- & -- & -- & -- & 13.1 \\
\hline \multirow{2}{*}{$\begin{array}{l}\text { Theis } \\
\text { recov- } \\
\text { ery }\end{array}$} & Observation well 1 & 580 & -- & 1.105 & -- & -- & -- & -- & -- & -- & 12.9 \\
\hline & Observation well 2 & 540 & -- & 1.111 & -- & -- & -- & -- & -- & -- & 12.0 \\
\hline \multicolumn{2}{|c|}{ Average graphical methods } & 600 & $4.4 \times 10-5$ & & & & & & & & 13.2 \\
\hline \multicolumn{2}{|c|}{ Average all methods } & 540 & $5.0 \times 10-5$ & & & & & & & & 12.1 \\
\hline
\end{tabular}

average transmissivity for the other three methods, which were developed for leaky aquifers, was $490 \mathrm{ft}^{2} / \mathrm{d}$.

The storage coefficient estimated using the six methods ranged from 4.2 to $5.7 \times 10^{-5}$. As shown in table 3, the average storage coefficient for the fitted methods, Theis, Hantush, Hantush-Jacob, and Neuman-Witherspoon, was $5.1 \times 10^{-5}$; the average storage coefficient for the Cooper-Jacob graphical method was $4.4 \times 10^{-5}$; and the average storage coefficient for all six methods was $5.0 \times 10^{-5}$. The average storage coefficient for the two methods developed for nonleaky aquifers, Theis and Cooper-Jacob, was $4.9 \times 10^{-5}$. The average storage coefficient for the other three methods with estimated values, which were developed for leaky aquifers, was $5.0 \times 10^{-5}$.
The hydraulic conductivity was estimated by dividing the estimated transmissivity by $45 \mathrm{ft}$, which is the thickness of the aquifer at the production well. As shown in table 3, it ranged from 10.0 to $14.4 \mathrm{ft} / \mathrm{d}$. The average hydraulic conductivity for all six methods was $12.1 \mathrm{ft} / \mathrm{d}$.

\section{Summary}

The U.S. Geological Survey, in cooperation with the Shakopee Mdewakanton Sioux Community, conducted an aquifer test December 6-22, 2004, to improve definition of the hydraulic properties of the Ironton and Galesville Sandstones 
(A) Observation well 1

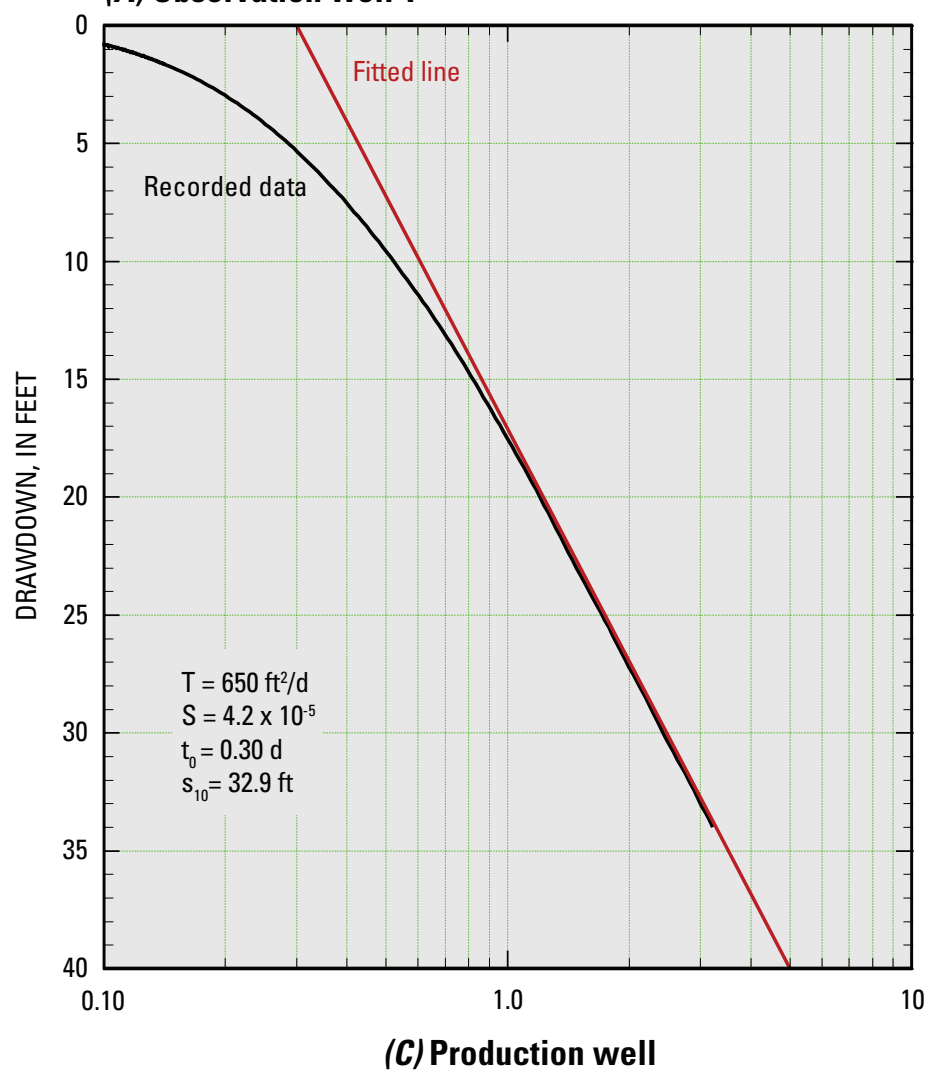

(B) Observation well 2

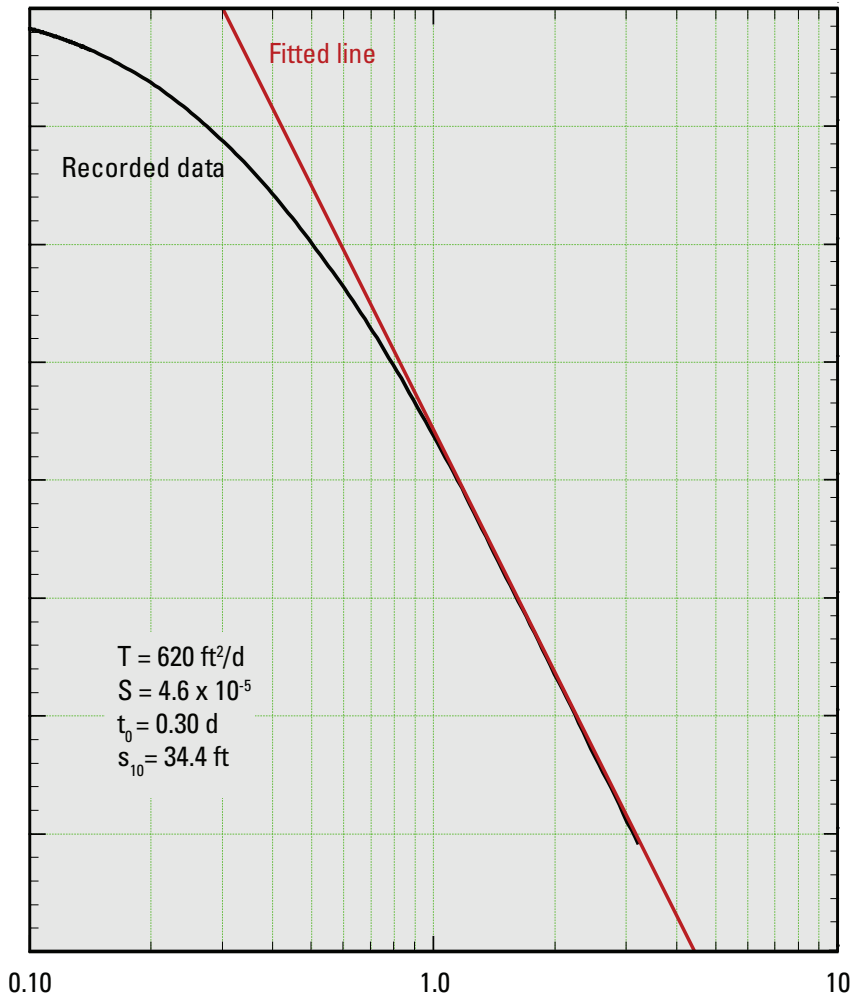

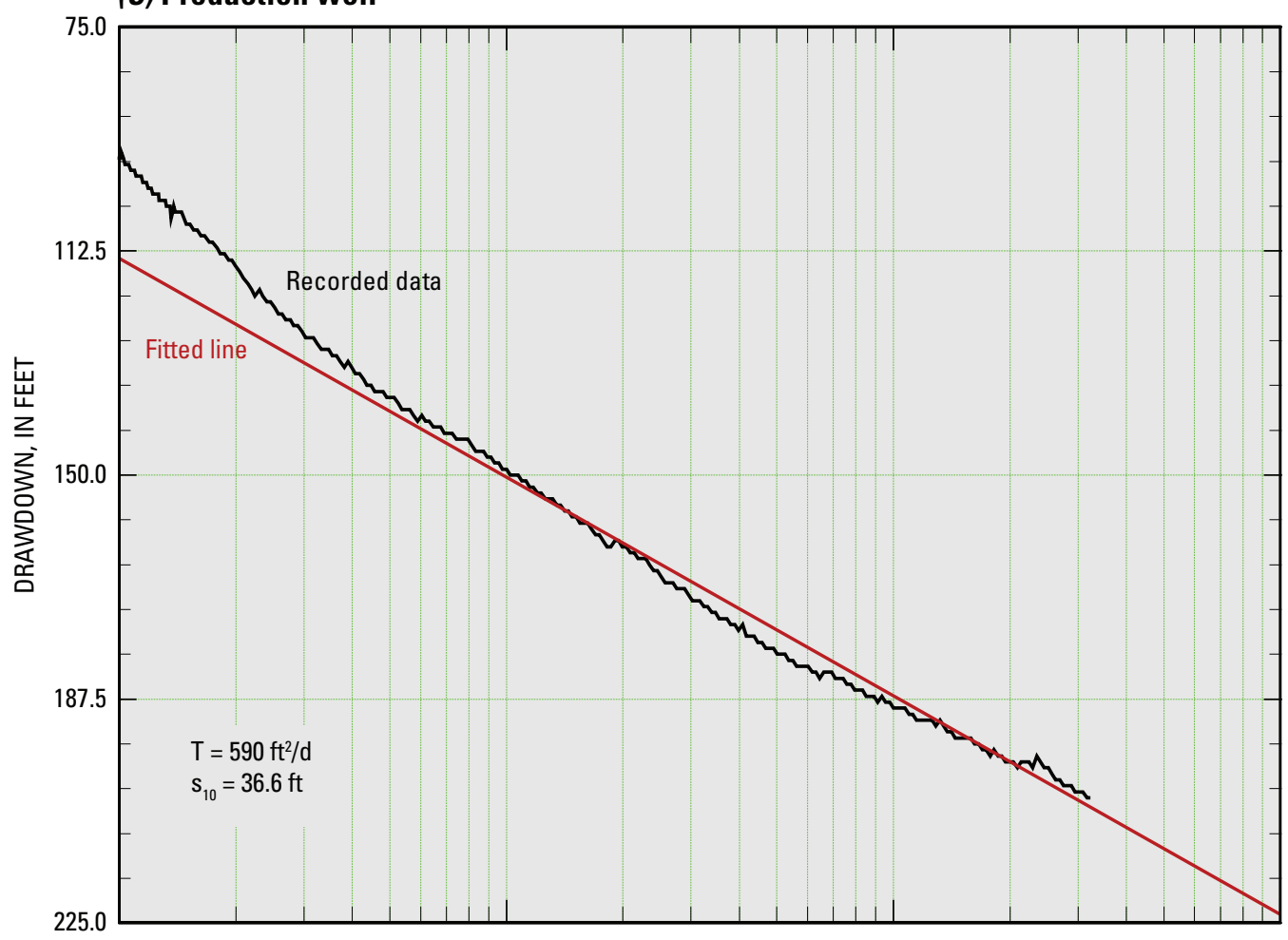

Figure 9. Cooper-Jacob method of solution applied to recorded drawdown of $(\boldsymbol{A})$ observation well 1, (B) observation well 2, and (C) production well, December 6-9, 2004. [ $T=$ transmissivity; $S=$ storage coefficient; $t_{0}=$ point where line crosses axis at 0 drawdown; $\mathrm{S}_{10}=$ drawdown across one log cycle] 


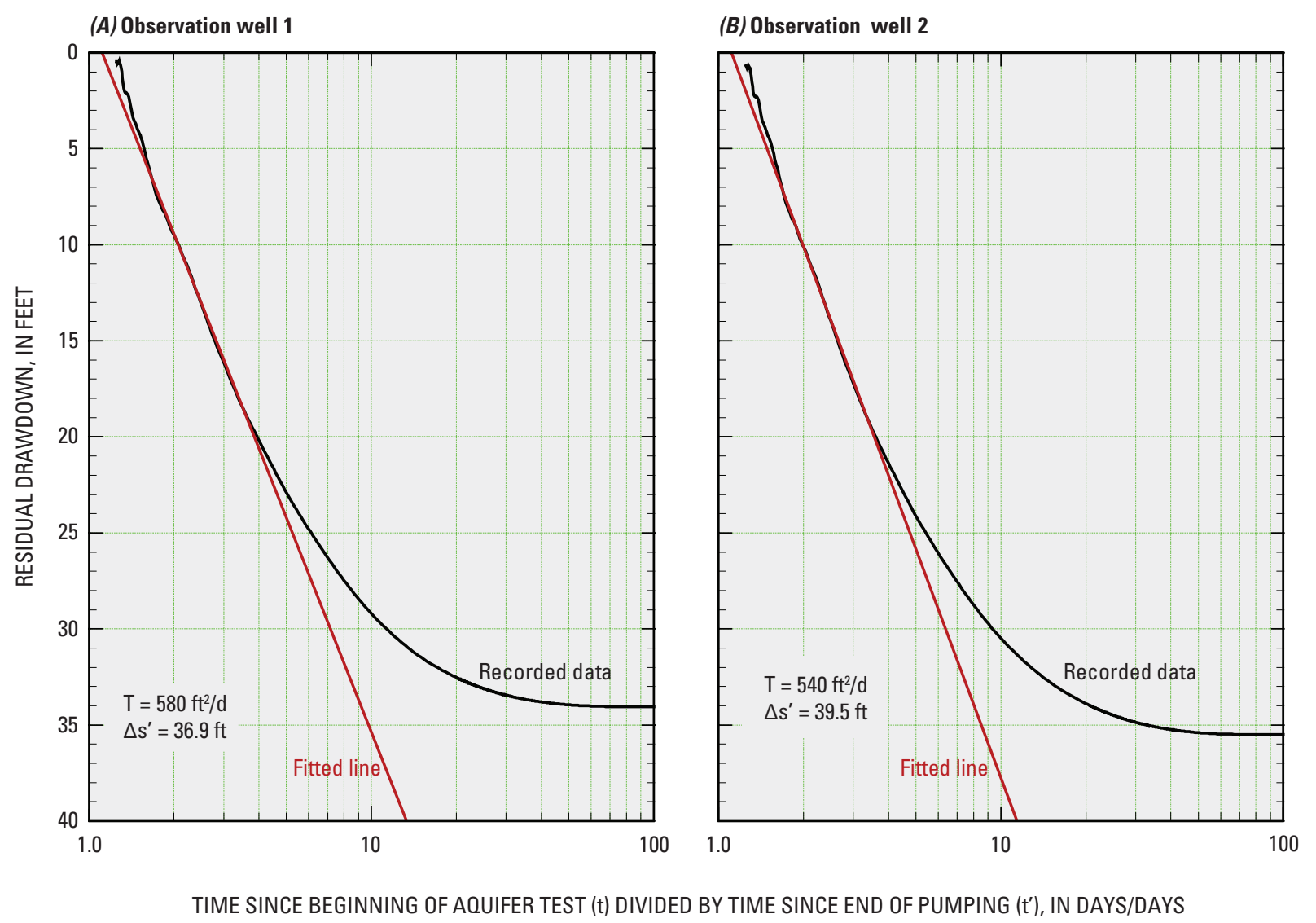

Figure 10. Theis recovery method applied to residual recovery curves for $(\boldsymbol{A})$ observation well 1 and $(\boldsymbol{B})$ observation well 2, December 9-22, 2004. [ $T$ = transmissivity drawdown per log cycle; $\Delta \mathbf{s}^{\prime}=$ change in coefficient of storage]

beneath the Shakopee Community in southeastern Minnesota. One production well and two observation wells were used in the aquifer test. The production well, Franconia-IrontonGalesville Well No. 2, is cased with a 20-in. diameter steel casing from 0 to $179 \mathrm{ft}$ and a 16-in. diameter steel casing from 170 to $570 \mathrm{ft}$, and is an open hole from 570 to $667 \mathrm{ft}$. The casing ends about $25 \mathrm{ft}$ above the bottom of the Franconia Formation. The bottom of the pump is at a depth of $465 \mathrm{ft}$. Observation well 1 is located 3,247 ft northwest of the production well. The well is cased with an 8 -in. diameter steel casing from 0 to $145 \mathrm{ft}$, a 4-in. diameter steel casing from 145 to $520 \mathrm{ft}$, and is a 4-in. diameter open hole from 520 to $620 \mathrm{ft}$. Observation well 2 is located 3,049 ft southeast of the production well. The well is cased with a 8-in. diameter steel casing from 0 to $252 \mathrm{ft}$, a 4-in. diameter steel casing from 252 to $623 \mathrm{ft}$, and is a 4-in. diameter open hole from 623 to $712 \mathrm{ft}$. Both observation wells were cased to about the same elevation as the production well so that they were open to the same formations.

The aquifer test began at 10:30 a.m. December 6, 2004. The production well was pumped at about $600 \mathrm{gal} / \mathrm{min}$. The pump was shut off December 9, 2004, at 3:26 p.m. Drawdown and recovery were recorded in the production well and both observation wells December 6-22.
Four curve-fitting methods and two graphical methods were used to estimate the transmissivity and storage coefficient of the Ironton and Galesville Sandstones. The four curvefitting methods were the Theis, Hantush, Hantush-Jacob, and Neumann-Witherspoon methods. These methods were applied to the drawdown and residual recovery curves of the observation wells. The two graphical methods were the Cooper-Jacob method and the Theis recovery method. The Cooper-Jacob method was applied to the drawdown curve of the production well and the drawdown curves of the two observation wells. The Theis recovery method was applied to the residual drawdown curves of the two observation wells

The transmissivity estimated using the six methods ranged from 450 to $650 \mathrm{ft}^{2} / \mathrm{d}$. The average transmissivity for the fitted methods, Theis, Hantush, Hantush-Jacob, and Neuman-Witherspoon, was $510 \mathrm{ft}^{2} / \mathrm{d}$; the average transmissivity for the Cooper-Jacob and Theis recovery graphical methods was $600 \mathrm{ft}^{2} / \mathrm{d}$; and the average transmissivity for all six methods was $540 \mathrm{ft}^{2} / \mathrm{d}$. The average transmissivity for the three methods developed for nonleaky aquifers, Theis, Cooper-Jacob, and Theis recovery, was $590 \mathrm{ft}^{2} / \mathrm{d}$. The average transmissivity for the other three methods, which were developed for leaky aquifers, was $490 \mathrm{ft}^{2} / \mathrm{d}$. 
The storage coefficient estimated using the six methods ranged from 4.2 to $5.7 \times 10^{-5}$. The average storage coefficient for the fitted methods, Theis, Hantush, Hantush-Jacob, and Neuman-Witherspoon, was $5.1 \times 10^{-5}$; the average storage coefficient for the Cooper-Jacob graphical method was $4.4 \mathrm{x}$ $10^{-5}$; and the average storage coefficient for all six methods was $5.0 \times 10^{-5}$. The average storage coefficient for the two methods developed for nonleaky aquifers, Theis and CooperJacob, was $4.9 \times 10^{-5}$. The average storage coefficient for the other three methods with estimated values, which were developed for leaky aquifers, was $5.0 \times 10^{-5}$.

The hydraulic conductivity was estimated by dividing the estimated transmissivity by $45 \mathrm{ft}$. It ranged from 10.0 to $14.4 \mathrm{ft} / \mathrm{d}$. The average hydraulic conductivity for all six methods was $12.1 \mathrm{ft} / \mathrm{d}$.

\section{References Cited}

Ferris, J.G., Knowles, D.B., Brown, R.H., and Stallman, R.W., 1962, Theory of aquifer tests: U.S. Geological Survey Water-Supply Paper 1536-E, 174 p.

Hantush, M.S., 1960, Modification of the theory of leaky aquifers: Journal of Geophysical Research, v. 65, no. 11, p. 3713-3725.

Hantush, M.S., and Jacob, C.E., 1955, Non-steady radial flow in an infinite leaky aquifer: American Geophysical Union Transactions, v. 36, p. 95-100.

Heath, R.C., 1983, Basic ground-water hydrology: U.S. Geological Survey Water-Supply Paper 2220, 84 p.
Hydrosolve, 2000, AQTESOLV for Windows user guide: Reston, Virginia, Hydrosolve, Inc., unpaged.

Jacob, C.E., 1963, The recovery method for determining the coefficient of transmissibility, in Bentall, Ray, compiler, Methods of determining permeability, transmissibility and drawdown: U.S. Geological Survey Water-Supply Paper 1536-I, p. 283-292.

Miller, R.T., and Delin, G.N., 1993, Cyclic injection, storage, and withdrawal of heated water in a sandstone aquifer at St. Paul, Minnesota-field observations, preliminary model analysis, and aquifer thermal efficiency: U.S. Geological Survey Professional Paper 1530-A, 55 p.

Mossler, J.H., and Tipping, R.G., 2000, Bedrock-geology and structure of the seven-county Twin Cities metropolitan area, Minnesota: University of Minnesota, Minnesota Geological Survey Miscellaneous Map Series Map M-104, 1 pl.

Neuman, S.P., and Witherspoon, P.A., 1969, Theory of flow in a confined two aquifer system: Water Resources Research, v. 5 , no. 4 , p. $803-816$.

Runkel, A.C., Tipping, R.G., Alexander, E.C., Jr., Green, J.A., Mossler, J.H, and Alexander, S.C., 2003, Hydrogeology of the Paleozoic bedrock in southeastern Minnesota: Minnesota Geological Survey Report of Investigations 61, 105 p., $2 \mathrm{pl}$.

Todd, D.K., 1980, Groundwater hydrology (2d ed.): New York, John Wiley \& Sons, 535 p. 


\section{Appendix}


Table A1. Recorded water levels in production well, Shakopee Mdewakanton Sioux Community, December 6-22, 2004.

[Aquifer test began at 10:30 a.m., December 6, 2004]

\begin{tabular}{|c|c|c|c|c|c|c|c|}
\hline $\begin{array}{c}\text { Time since } \\
\text { beginning of } \\
\text { pumping, in } \\
\text { days }\end{array}$ & $\begin{array}{c}\text { Recorded } \\
\text { water level, } \\
\text { in feet below } \\
\text { datum }\end{array}$ & $\begin{array}{c}\text { Time since } \\
\text { beginning of } \\
\text { pumping, in } \\
\text { days }\end{array}$ & $\begin{array}{c}\text { Recorded } \\
\text { water level, } \\
\text { in feet below } \\
\text { datum }\end{array}$ & $\begin{array}{c}\text { Time since } \\
\text { beginning of } \\
\text { pumping, in } \\
\text { days }\end{array}$ & $\begin{array}{c}\text { Recorded } \\
\text { water level, } \\
\text { in feet below } \\
\text { datum }\end{array}$ & $\begin{array}{c}\text { Time since } \\
\text { beginning of } \\
\text { pumping, in } \\
\text { days }\end{array}$ & $\begin{array}{c}\text { Recorded } \\
\text { water level, } \\
\text { in feet below } \\
\text { datum }\end{array}$ \\
\hline 0 & 122 & 0.022 & 241 & 0.101 & 272 & 0.499 & 302 \\
\hline .001 & 146 & .023 & 242 & .108 & 273 & .526 & 303 \\
\hline .001 & 163 & .024 & 243 & .114 & 274 & .550 & 304 \\
\hline .002 & 178 & .025 & 244 & .119 & 275 & .597 & 305 \\
\hline .003 & 190 & .026 & 245 & .126 & 276 & .631 & 306 \\
\hline .003 & 194 & .027 & 246 & .133 & 277 & .731 & 307 \\
\hline .005 & 195 & .029 & 247 & .140 & 278 & .783 & 308 \\
\hline .006 & 198 & .030 & 248 & .148 & 279 & .833 & 309 \\
\hline .006 & 203 & .031 & 249 & .156 & 280 & .915 & 310 \\
\hline .007 & 206 & .033 & 250 & .163 & 281 & .974 & 311 \\
\hline .008 & 209 & .034 & 251 & .167 & 282 & 1.079 & 312 \\
\hline .008 & 213 & .036 & 252 & .174 & 283 & 1.136 & 313 \\
\hline .009 & 216 & .037 & 253 & .181 & 284 & 1.285 & 314 \\
\hline .01 & 217 & .038 & 254 & .205 & 285 & 1.355 & 315 \\
\hline .010 & 220 & .041 & 256 & .215 & 286 & 1.417 & 316 \\
\hline .011 & 222 & .044 & 257 & .229 & 287 & 1.545 & 317 \\
\hline .012 & 223 & .046 & 258 & .238 & 288 & 1.650 & 318 \\
\hline .013 & 225 & .049 & 259 & .251 & 289 & 1.767 & 319 \\
\hline .013 & 226 & .053 & 260 & .258 & 290 & 1.906 & 320 \\
\hline .014 & 227 & .054 & 261 & .272 & 291 & 2.061 & 321 \\
\hline .015 & 228 & .057 & 262 & .288 & 292 & 2.294 & 322 \\
\hline .015 & 230 & .059 & 263 & .302 & 293 & 2.587 & 323 \\
\hline .016 & 231 & .065 & 264 & .321 & 294 & 2.678 & 324 \\
\hline .017 & 232 & .068 & 265 & .333 & 295 & 2.904 & 325 \\
\hline .017 & 233 & .074 & 266 & .345 & 296 & 3.032 & 326 \\
\hline .018 & 235 & .081 & 267 & .376 & 297 & 3.190 & 326 \\
\hline .020 & 236 & .083 & 268 & .392 & 298 & 3.191 & 339 \\
\hline .020 & 237 & .087 & 269 & .416 & 299 & 3.192 & 325 \\
\hline .021 & 238 & .090 & 270 & .436 & 300 & 3.192 & 305 \\
\hline .022 & 240 & .097 & 271 & .463 & 301 & 3.193 & 291 \\
\hline
\end{tabular}


Table A1. Recorded water levels in production well, Shakopee Mdewakanton Sioux Community, December 6-22, 2004.-Continued

[Aquifer test began at 10:30 a.m., December 6, 2004]

\begin{tabular}{|c|c|c|c|c|c|c|c|}
\hline $\begin{array}{c}\text { Time since } \\
\text { beginning of } \\
\text { pumping, in } \\
\text { days }\end{array}$ & $\begin{array}{c}\text { Recorded } \\
\text { water level, } \\
\text { in feet below } \\
\text { datum }\end{array}$ & $\begin{array}{l}\text { Time since } \\
\text { beginning of } \\
\text { pumping, in } \\
\text { days }\end{array}$ & $\begin{array}{c}\text { Recorded } \\
\text { water level, } \\
\text { in feet below } \\
\text { datum }\end{array}$ & $\begin{array}{c}\text { Time since } \\
\text { beginning of } \\
\text { pumping, in } \\
\text { days }\end{array}$ & $\begin{array}{c}\text { Recorded } \\
\text { water level, } \\
\text { in feet below } \\
\text { datum }\end{array}$ & $\begin{array}{c}\text { Time since } \\
\text { beginning of } \\
\text { pumping, in } \\
\text { days }\end{array}$ & $\begin{array}{c}\text { Recorded } \\
\text { water level, } \\
\text { in feet below } \\
\text { datum }\end{array}$ \\
\hline 3.194 & 294 & 3.215 & 199 & 3.245 & 184 & 3.914 & 144 \\
\hline 3.194 & 292 & 3.216 & 195 & 3.246 & 184 & 3.990 & 143 \\
\hline 3.195 & 288 & 3.217 & 193 & 3.247 & 177 & 4.008 & 142 \\
\hline 3.196 & 287 & 3.217 & 188 & 3.247 & 188 & 4.078 & 141 \\
\hline 3.197 & 288 & 3.218 & 185 & 3.248 & 195 & 4.156 & 140 \\
\hline 3.197 & 293 & 3.220 & 184 & 3.249 & 183 & 4.235 & 139 \\
\hline 3.198 & 301 & 3.221 & 182 & 3.249 & 176 & 4.301 & 138 \\
\hline 3.199 & 297 & 3.223 & 181 & 3.250 & 177 & 4.392 & 137 \\
\hline 3.199 & 299 & 3.224 & 178 & 3.251 & 176 & 4.724 & 136 \\
\hline 3.200 & 302 & 3.226 & 181 & 3.251 & 180 & 4.824 & 135 \\
\hline 3.201 & 304 & 3.227 & 219 & 3.252 & 178 & 4.944 & 134 \\
\hline 3.201 & 303 & 3.228 & 192 & 3.343 & 164 & 5.107 & 133 \\
\hline 3.202 & 302 & 3.229 & 187 & 3.351 & 163 & 5.272 & 132 \\
\hline 3.203 & 301 & 3.230 & 181 & 3.367 & 162 & 5.419 & 131 \\
\hline 3.203 & 297 & 3.231 & 180 & 3.387 & 161 & 5.647 & 130 \\
\hline 3.204 & 298 & 3.231 & 175 & 3.405 & 160 & 5.953 & 129 \\
\hline 3.205 & 292 & 3.232 & 173 & 3.415 & 159 & 6.167 & 128 \\
\hline 3.206 & 290 & 3.233 & 171 & 3.437 & 157 & 6.433 & 127 \\
\hline 3.206 & 266 & 3.234 & 170 & 3.461 & 156 & 6.743 & 126 \\
\hline 3.207 & 250 & 3.236 & 174 & 3.472 & 155 & 6.958 & 125 \\
\hline 3.208 & 240 & 3.236 & 170 & 3.494 & 154 & 6.959 & 124 \\
\hline 3.208 & 235 & 3.238 & 169 & 3.506 & 153 & 6.981 & 305 \\
\hline 3.209 & 231 & 3.238 & 171 & 3.529 & 152 & 6.981 & 309 \\
\hline 3.210 & 223 & 3.240 & 177 & 3.558 & 151 & 6.982 & 298 \\
\hline 3.210 & 216 & 3.240 & 179 & 3.695 & 150 & 6.983 & 305 \\
\hline 3.211 & 211 & 3.241 & 172 & 3.709 & 149 & 6.983 & 306 \\
\hline 3.212 & 208 & 3.242 & 171 & 3.752 & 148 & 6.984 & 141 \\
\hline 3.212 & 204 & 3.243 & 174 & 3.784 & 147 & 6.985 & 232 \\
\hline 3.214 & 203 & 3.244 & 165 & 3.863 & 146 & 6.985 & 171 \\
\hline 3.215 & 201 & 3.244 & 166 & 3.879 & 145 & 6.986 & 182 \\
\hline
\end{tabular}


Table A1. Recorded water levels in production well, Shakopee Mdewakanton Sioux Community, December 6-22, 2004.-Continued

\begin{tabular}{|c|c|c|c|c|c|c|c|}
\hline $\begin{array}{c}\text { Time since } \\
\text { beginning of } \\
\text { pumping, in } \\
\text { days }\end{array}$ & $\begin{array}{c}\text { Recorded } \\
\text { water level, } \\
\text { in feet below } \\
\text { datum }\end{array}$ & $\begin{array}{c}\text { Time since } \\
\text { beginning of } \\
\text { pumping, in } \\
\text { days }\end{array}$ & $\begin{array}{c}\text { Recorded } \\
\text { water level, } \\
\text { in feet below } \\
\text { datum }\end{array}$ & $\begin{array}{c}\text { Time since } \\
\text { beginning of } \\
\text { pumping, in } \\
\text { days }\end{array}$ & $\begin{array}{c}\text { Recorded } \\
\text { water level, } \\
\text { in feet below } \\
\text { datum }\end{array}$ & $\begin{array}{c}\text { Time since } \\
\text { beginning of } \\
\text { pumping, in } \\
\text { days }\end{array}$ & $\begin{array}{c}\text { Recorded } \\
\text { water level, } \\
\text { in feet below } \\
\text { datum }\end{array}$ \\
\hline 6.987 & 193 & 6.994 & 140 & 7.020 & 128 & 10.210 & 116 \\
\hline 6.988 & 200 & 6.994 & 138 & 7.021 & 127 & 10.210 & 115 \\
\hline 6.988 & 204 & 6.995 & 136 & 7.022 & 126 & 11.128 & 114 \\
\hline 6.989 & 190 & 6.997 & 135 & 7.920 & 117 & 15.483 & 113 \\
\hline 6.990 & 167 & 7.000 & 134 & 7.040 & 123 & 15.555 & 114 \\
\hline 6.990 & 154 & 7.002 & 133 & 7.079 & 122 & & \\
\hline 6.991 & 151 & 7.003 & 132 & 7.442 & 121 & & \\
\hline 6.992 & 149 & 7.007 & 131 & 7.503 & 120 & & \\
\hline 6.992 & 145 & 7.009 & 130 & 7.506 & 119 & & \\
\hline 6.993 & 142 & 7.010 & 129 & 7.765 & 118 & & \\
\hline
\end{tabular}


Table A2. Measured water levels in production well, Shakopee Mdewakanton Sioux Community, southeastern Minnesota,

December 9, 2004.

\begin{tabular}{|c|c|c|}
\hline $\begin{array}{c}\text { Time } \\
\text { (24-hour) }\end{array}$ & $\begin{array}{l}\text { Water level } \\
\text { below top of casing } \\
\text { (feet) }\end{array}$ & $\begin{array}{c}\text { Water-surface } \\
\text { elevation (feet above } \\
\text { North American } \\
\text { Vertical Datum of 1988) }\end{array}$ \\
\hline $15: 25$ & 405 & 580 \\
\hline $15: 27$ & 378 & 607 \\
\hline $15: 28$ & 365 & 620 \\
\hline $15: 29$ & 355 & 630 \\
\hline $15: 30$ & 346 & 639 \\
\hline $15: 31$ & 340 & 645 \\
\hline $15: 32$ & 336 & 649 \\
\hline $15: 33$ & 332 & 653 \\
\hline $15: 34$ & 328 & 657 \\
\hline $15: 35$ & 325.5 & 659.5 \\
\hline $15: 36$ & 323 & 662 \\
\hline $15: 37$ & 321 & 664 \\
\hline $15: 38$ & 319 & 666 \\
\hline $15: 39$ & 317.1 & 667.9 \\
\hline $15: 40$ & 315.2 & 669.8 \\
\hline $15: 41$ & 313.7 & 671.3 \\
\hline $15: 46$ & 308 & 677 \\
\hline $15: 51$ & 303 & 682 \\
\hline $15: 56$ & 299.5 & 685.5 \\
\hline 16:01 & 297 & 688 \\
\hline $16: 06$ & 294.5 & 690.5 \\
\hline $16: 11$ & 292 & 693 \\
\hline $16: 16$ & 289 & 696 \\
\hline $16: 21$ & 287.3 & 697.7 \\
\hline $16: 26$ & 286 & 699 \\
\hline
\end{tabular}


Table A3. Measured water levels in observation well 1 and observation well 2, Shakopee Mdewakanton Sioux Community, southeastern Minnesota, December 6-22, 2004.

[Aquifer test began 10:30 a.m., December 6, 2004. Pump was turned off 3:26 p.m., December 9, 2004. Water level was measured in observation well 1 until 10:27 a.m., December 22, 2004. Water level was measured in observation well 2 until 11:55 a.m., December 22, 2004. --, no data]

\begin{tabular}{|c|c|c|c|c|c|c|c|}
\hline \multicolumn{4}{|c|}{ Observation well 1} & \multicolumn{4}{|c|}{ Observation well 2} \\
\hline $\begin{array}{l}\text { Time since } \\
\text { beginning } \\
\text { of aquifer } \\
\text { test (days) }\end{array}$ & $\begin{array}{l}\text { Draw- } \\
\text { down } \\
\text { (feet) }\end{array}$ & $\begin{array}{c}\text { Recovery } \\
\text { (feet) }\end{array}$ & $\begin{array}{c}\text { Elevation } \\
\text { above North } \\
\text { American } \\
\text { Vertical Da- } \\
\text { tum of } 1988 \\
\text { (feet) }\end{array}$ & $\begin{array}{l}\text { Time since } \\
\text { beginning } \\
\text { of aquifer } \\
\text { test (days) }\end{array}$ & $\begin{array}{l}\text { Draw- } \\
\text { down } \\
\text { (feet) }\end{array}$ & $\begin{array}{c}\text { Recovery } \\
\text { (feet) }\end{array}$ & Elevation (feet) \\
\hline 0 & 0 & -- & 764.32 & 0 & 0 & -- & 779.82 \\
\hline .034 & 0 & -- & 764.32 & .036 & 0 & -- & 779.81 \\
\hline .035 & .01 & -- & 764.31 & .037 & .01 & -- & 779.80 \\
\hline .036 & .01 & -- & 764.31 & .038 & .01 & -- & 779.80 \\
\hline .037 & .02 & -- & 764.30 & .039 & .02 & -- & 779.80 \\
\hline .039 & .02 & -- & 764.30 & .040 & .02 & -- & 779.79 \\
\hline .040 & .02 & -- & 764.30 & .041 & .03 & -- & 779.79 \\
\hline .041 & .03 & -- & 764.30 & .042 & .03 & -- & 779.78 \\
\hline .042 & .04 & -- & 764.29 & .043 & .04 & -- & 779.77 \\
\hline .043 & .04 & -- & 764.28 & .044 & .04 & -- & 779.77 \\
\hline .044 & .05 & -- & 764.27 & .046 & .06 & -- & 779.75 \\
\hline .045 & .05 & -- & 764.27 & .050 & .09 & -- & 779.73 \\
\hline .046 & .06 & -- & 764.26 & .054 & .13 & -- & 779.68 \\
\hline .047 & .07 & -- & 764.25 & .058 & .18 & -- & 779.64 \\
\hline .048 & .08 & -- & 764.24 & .063 & .24 & -- & 779.58 \\
\hline .049 & .08 & -- & 764.24 & .069 & .31 & -- & 779.51 \\
\hline .050 & .09 & -- & 764.24 & .074 & .39 & -- & 779.43 \\
\hline .051 & .10 & -- & 764.22 & .080 & .48 & -- & 779.34 \\
\hline .052 & .11 & -- & 764.21 & .086 & .58 & -- & 779.24 \\
\hline .053 & .12 & -- & 764.20 & .093 & .71 & -- & 779.11 \\
\hline .054 & .13 & -- & 764.19 & .100 & .85 & -- & 778.97 \\
\hline .055 & .14 & -- & 764.18 & .108 & 1.02 & -- & 778.80 \\
\hline .056 & .15 & -- & 764.17 & .117 & 1.20 & -- & 778.62 \\
\hline .057 & .16 & -- & 764.16 & .126 & 1.40 & -- & 778.41 \\
\hline .058 & .17 & -- & 764.15 & .136 & 1.63 & -- & 778.19 \\
\hline .059 & .18 & -- & 764.14 & .147 & 1.87 & -- & 777.94 \\
\hline .060 & .19 & -- & 764.14 & .159 & 2.16 & -- & 777.66 \\
\hline .062 & .21 & -- & 764.11 & .171 & 2.45 & -- & 777.37 \\
\hline .064 & .23 & -- & 764.09 & .185 & 2.80 & -- & 777.02 \\
\hline .066 & .26 & -- & 764.06 & .200 & 3.14 & -- & 776.68 \\
\hline
\end{tabular}


Table A3. Measured water levels in observation well 1 and observation well 2, Shakopee Mdewakanton Sioux Community, southeastern Minnesota, December 6-22, 2004.-Continued

[Aquifer test began 10:30 a.m., December 6, 2004. Pump was turned off 3:26 p.m., December 9, 2004. Water level was measured in observation well 1 until 10:27 a.m., December 22, 2004. Water level was measured in observation well 2 until 11:55 a.m., December 22, 2004. --, no data]

\begin{tabular}{|c|c|c|c|c|c|c|c|}
\hline \multicolumn{4}{|c|}{ Observation well 1} & \multicolumn{4}{|c|}{ Observation well 2} \\
\hline $\begin{array}{l}\text { Time since } \\
\text { beginning } \\
\text { of aquifer } \\
\text { test (days) }\end{array}$ & $\begin{array}{l}\text { Draw- } \\
\text { down } \\
\text { (feet) }\end{array}$ & $\begin{array}{c}\text { Recovery } \\
\text { (feet) }\end{array}$ & $\begin{array}{c}\text { Elevation } \\
\text { above North } \\
\text { American } \\
\text { Vertical Da- } \\
\text { tum of } 1988 \\
\text { (feet) }\end{array}$ & $\begin{array}{l}\text { Time since } \\
\text { beginning } \\
\text { of aquifer } \\
\text { test (days) }\end{array}$ & $\begin{array}{l}\text { Draw- } \\
\text { down } \\
\text { (feet) }\end{array}$ & $\begin{array}{l}\text { Recovery } \\
\text { (feet) }\end{array}$ & Elevation (feet) \\
\hline 0.068 & 0.29 & -- & 764.04 & 0.216 & 3.53 & -- & 776.28 \\
\hline .071 & .33 & -- & 764.00 & .233 & 3.96 & -- & 775.86 \\
\hline .074 & .37 & -- & 763.96 & .251 & 4.41 & -- & 775.41 \\
\hline .078 & .42 & -- & 763.90 & .272 & 4.90 & -- & 774.91 \\
\hline .081 & .47 & -- & 763.86 & .293 & 5.42 & -- & 774.40 \\
\hline .084 & .52 & -- & 763.80 & .317 & 5.98 & -- & 773.84 \\
\hline .088 & .58 & -- & 763.74 & .342 & 6.56 & -- & 773.26 \\
\hline .093 & .67 & -- & 763.65 & .369 & 7.17 & -- & 772.64 \\
\hline .097 & .75 & -- & 763.58 & .398 & 7.82 & -- & 771.99 \\
\hline .102 & .84 & -- & 763.48 & .430 & 8.52 & -- & 771.30 \\
\hline .108 & .93 & -- & 763.39 & .464 & 9.23 & -- & 770.59 \\
\hline .114 & 1.05 & -- & 763.27 & .501 & 9.98 & -- & 769.84 \\
\hline .120 & 1.18 & -- & 763.14 & .541 & 10.76 & -- & 769.06 \\
\hline .127 & 1.32 & -- & 763.00 & .585 & 11.55 & -- & 768.27 \\
\hline .134 & 1.48 & -- & 762.84 & .631 & 12.38 & -- & 767.44 \\
\hline .142 & 1.65 & -- & 762.68 & .681 & 13.26 & -- & 766.56 \\
\hline .151 & 1.84 & -- & 762.49 & .736 & 14.16 & -- & 765.66 \\
\hline .160 & 2.05 & -- & 762.28 & .795 & 15.11 & -- & 764.71 \\
\hline .170 & 2.27 & -- & 762.05 & .858 & 16.08 & -- & 763.73 \\
\hline .181 & 2.52 & -- & 761.81 & .926 & 17.10 & -- & 762.72 \\
\hline .193 & 2.78 & -- & 761.54 & 1.000 & 18.11 & -- & 761.71 \\
\hline .205 & 3.08 & -- & 761.24 & 1.080 & 19.17 & -- & 760.65 \\
\hline .219 & 3.41 & -- & 760.91 & 1.166 & 20.22 & -- & 759.59 \\
\hline .234 & 3.76 & -- & 760.56 & 1.260 & 21.37 & -- & 758.45 \\
\hline .250 & 4.14 & -- & 760.19 & 1.360 & 22.52 & -- & 757.30 \\
\hline .267 & 4.54 & -- & 759.78 & 1.468 & 23.68 & -- & 756.14 \\
\hline .285 & 4.97 & -- & 759.35 & 1.585 & 24.79 & -- & 755.02 \\
\hline .305 & 5.44 & -- & 758.88 & 1.712 & 25.89 & -- & 753.93 \\
\hline .327 & 5.94 & -- & 758.39 & 1.848 & 27.06 & -- & 752.76 \\
\hline .350 & 6.46 & -- & 757.87 & 1.996 & 28.24 & -- & 751.57 \\
\hline
\end{tabular}


Table A3. Measured water levels in observation well 1 and observation well 2, Shakopee Mdewakanton Sioux Community, southeastern Minnesota, December 6-22, 2004.—Continued

[Aquifer test began 10:30 a.m., December 6, 2004. Pump was turned off 3:26 p.m., December 9, 2004. Water level was measured in observation well 1 until 10:27 a.m., December 22, 2004. Water level was measured in observation well 2 until 11:55 a.m., December 22, 2004. --, no data]

\begin{tabular}{|c|c|c|c|c|c|c|c|}
\hline \multicolumn{4}{|c|}{ Observation well 1} & \multicolumn{4}{|c|}{ Observation well 2} \\
\hline $\begin{array}{l}\text { Time since } \\
\text { beginning } \\
\text { of aquifer } \\
\text { test (days) }\end{array}$ & $\begin{array}{l}\text { Draw- } \\
\text { down } \\
\text { (feet) }\end{array}$ & $\begin{array}{c}\text { Recovery } \\
\text { (feet) }\end{array}$ & $\begin{array}{c}\text { Elevation } \\
\text { above North } \\
\text { American } \\
\text { Vertical Da- } \\
\text { tum of } 1988 \\
\text { (feet) }\end{array}$ & $\begin{array}{l}\text { Time since } \\
\text { beginning } \\
\text { of aquifer } \\
\text { test (days) }\end{array}$ & $\begin{array}{l}\text { Draw- } \\
\text { down } \\
\text { (feet) }\end{array}$ & $\begin{array}{l}\text { Recovery } \\
\text { (feet) }\end{array}$ & Elevation (feet) \\
\hline 0.403 & 7.60 & -- & 756.72 & 2.154 & 29.34 & -- & 750.47 \\
\hline .432 & 8.21 & -- & 756.11 & 2.327 & 30.55 & -- & 749.26 \\
\hline .464 & 8.86 & -- & 755.46 & 2.513 & 31.74 & -- & 748.07 \\
\hline .499 & 9.55 & -- & 754.78 & 2.712 & 32.84 & -- & 746.97 \\
\hline .536 & 10.26 & -- & 754.06 & 2.929 & 34.03 & -- & 745.78 \\
\hline 0.575 & 10.98 & -- & 753.34 & 3.162 & 35.16 & -- & 744.65 \\
\hline .618 & 11.73 & -- & 752.59 & 3.205 & 35.38 & -- & 744.44 \\
\hline .665 & 12.53 & -- & 751.79 & 3.207 & 35.38 & -0 & 744.44 \\
\hline .716 & 13.36 & -- & 750.96 & 3.208 & 35.39 & -.01 & 744.43 \\
\hline .770 & 14.23 & -- & 750.09 & 3.209 & 35.40 & -.02 & 744.42 \\
\hline .829 & 15.13 & -- & 749.20 & 3.210 & 35.40 & -.02 & 744.42 \\
\hline .892 & 16.07 & -- & 748.25 & 3.211 & 35.40 & -.02 & 744.42 \\
\hline .961 & 17.01 & -- & 747.31 & 3.212 & 35.40 & -.03 & 744.41 \\
\hline 1.034 & 17.97 & -- & 746.35 & 3.213 & 35.41 & -.03 & 744.41 \\
\hline 1.114 & 18.95 & -- & 745.37 & 3.214 & 35.41 & -.04 & 744.40 \\
\hline 1.201 & 19.98 & -- & 744.34 & 3.215 & 35.42 & -.04 & 744.40 \\
\hline 1.293 & 21.06 & -- & 743.27 & 3.216 & 35.43 & -.05 & 744.39 \\
\hline 1.393 & 22.14 & -- & 742.19 & 3.217 & 35.43 & -.05 & 744.39 \\
\hline 1.503 & 23.21 & -- & 741.11 & 3.218 & 35.43 & -.06 & 744.38 \\
\hline 1.619 & 24.24 & -- & 740.08 & 3.219 & 35.44 & -.06 & 744.38 \\
\hline 1.745 & 25.27 & -- & 739.06 & 3.220 & 35.45 & -.07 & 744.37 \\
\hline 1.882 & 26.36 & -- & 737.96 & 3.221 & 35.45 & -.07 & 744.37 \\
\hline 2.030 & 27.44 & -- & 736.89 & 3.222 & 35.46 & -.08 & 744.36 \\
\hline 2.189 & 28.47 & -- & 735.85 & 3.223 & 35.46 & -.08 & 744.36 \\
\hline 2.361 & 29.60 & -- & 734.72 & 3.224 & 35.46 & -.09 & 744.36 \\
\hline 2.546 & 30.68 & -- & 733.64 & 3.225 & 35.47 & -.09 & 744.35 \\
\hline 2.746 & 31.69 & -- & 732.63 & 3.226 & 35.47 & -.09 & 744.35 \\
\hline 3.020 & 33.10 & -- & 731.22 & 3.227 & 35.48 & -.10 & 744.34 \\
\hline 3.196 & 33.88 & -- & 730.44 & 3.228 & 35.48 & -.10 & 744.34 \\
\hline 3.205 & 33.92 & -- & 730.40 & 3.229 & 35.48 & -.10 & 744.34 \\
\hline
\end{tabular}


Table A3. Measured water levels in observation well 1 and observation well 2, Shakopee Mdewakanton Sioux Community, southeastern Minnesota, December 6-22, 2004.-Continued

[Aquifer test began 10:30 a.m., December 6, 2004. Pump was turned off 3:26 p.m., December 9, 2004. Water level was measured in observation well 1 until 10:27 a.m., December 22, 2004. Water level was measured in observation well 2 until 11:55 a.m., December 22, 2004. --, no data]

\begin{tabular}{|c|c|c|c|c|c|c|c|}
\hline \multicolumn{4}{|c|}{ Observation well 1} & \multicolumn{4}{|c|}{ Observation well 2} \\
\hline $\begin{array}{l}\text { Time since } \\
\text { beginning } \\
\text { of aquifer } \\
\text { test (days) }\end{array}$ & $\begin{array}{l}\text { Draw- } \\
\text { down } \\
\text { (feet) }\end{array}$ & $\begin{array}{c}\text { Recovery } \\
\text { (feet) }\end{array}$ & $\begin{array}{l}\text { Elevation } \\
\text { above North } \\
\text { American } \\
\text { Vertical Da- } \\
\text { tum of } 1988 \\
\text { (feet) }\end{array}$ & $\begin{array}{l}\text { Time since } \\
\text { beginning } \\
\text { of aquifer } \\
\text { test (days) }\end{array}$ & $\begin{array}{l}\text { Draw- } \\
\text { down } \\
\text { (feet) }\end{array}$ & $\begin{array}{l}\text { Recovery } \\
\text { (feet) }\end{array}$ & Elevation (feet) \\
\hline 3.206 & 33.92 & 0 & 730.40 & 3.230 & 35.49 & -0.11 & 744.33 \\
\hline 3.207 & 33.93 & -.01 & 730.39 & 3.231 & 35.49 & -.11 & 744.33 \\
\hline 3.208 & 33.93 & -.01 & 730.39 & 3.232 & 35.49 & -.12 & 744.32 \\
\hline 3.209 & 33.94 & -.02 & 730.38 & 3.233 & 35.49 & -.12 & 744.32 \\
\hline 3.212 & 33.95 & -.03 & 730.37 & 3.234 & 35.50 & -.12 & 744.32 \\
\hline 3.214 & 33.96 & -.04 & 730.36 & 3.235 & 35.50 & -.12 & 744.32 \\
\hline 3.215 & 33.96 & -.04 & 730.36 & 3.236 & 35.50 & -.13 & 744.31 \\
\hline 3.216 & 33.97 & -.05 & 730.35 & 3.237 & 35.51 & -.13 & 744.31 \\
\hline 3.217 & 33.97 & -.05 & 730.35 & 3.238 & 35.51 & -.13 & 744.31 \\
\hline 3.218 & 33.97 & -.06 & 730.34 & 3.239 & 35.51 & -.13 & 744.31 \\
\hline 3.219 & 33.98 & -0.06 & 730.34 & 3.240 & 35.51 & -0.13 & 744.31 \\
\hline 3.220 & 33.99 & -.07 & 730.33 & 3.241 & 35.51 & -.13 & 744.31 \\
\hline 3.221 & 33.99 & -.07 & 730.33 & 3.242 & 35.51 & -.14 & 744.30 \\
\hline 3.222 & 34.00 & -.08 & 730.32 & 3.245 & 35.51 & -.13 & 744.31 \\
\hline 3.223 & 34.00 & -.08 & 730.32 & 3.248 & 35.51 & -.13 & 744.31 \\
\hline 3.224 & 34.00 & -.08 & 730.32 & 3.253 & 35.50 & -.13 & 744.31 \\
\hline 3.225 & 34.01 & -.09 & 730.31 & 3.256 & 35.49 & -.12 & 744.32 \\
\hline 3.226 & 34.01 & -.09 & 730.31 & 3.260 & 35.48 & -.10 & 744.34 \\
\hline 3.227 & 34.01 & -.09 & 730.31 & 3.264 & 35.46 & -.08 & 744.36 \\
\hline 3.228 & 34.02 & -.10 & 730.30 & 3.268 & 35.43 & -.05 & 744.39 \\
\hline 3.229 & 34.02 & -.10 & 730.30 & 3.273 & 35.39 & -.01 & 744.43 \\
\hline 3.230 & 34.03 & -.11 & 730.30 & 3.279 & 35.33 & .04 & 744.48 \\
\hline 3.231 & 34.03 & -.11 & 730.29 & 3.285 & 35.28 & .10 & 744.54 \\
\hline 3.232 & 34.03 & -.11 & 730.29 & 3.291 & 35.21 & .17 & 744.61 \\
\hline 3.233 & 34.03 & -.12 & 730.28 & 3.298 & 35.12 & .25 & 744.69 \\
\hline 3.234 & 34.04 & -.12 & 730.28 & 3.305 & 35.02 & .36 & 744.80 \\
\hline 3.235 & 34.04 & -.12 & 730.28 & 3.313 & 34.91 & .47 & 744.91 \\
\hline 3.236 & 34.04 & -.12 & 730.28 & 3.322 & 34.78 & .60 & 745.04 \\
\hline 3.237 & 34.04 & -.12 & 730.28 & 3.331 & 34.63 & .75 & 745.19 \\
\hline 3.239 & 34.05 & -.13 & 730.27 & 3.341 & 34.47 & .91 & 745.35 \\
\hline
\end{tabular}


Table A3. Measured water levels in observation well 1 and observation well 2, Shakopee Mdewakanton Sioux Community, southeastern Minnesota, December 6-22, 2004.—Continued

[Aquifer test began 10:30 a.m., December 6, 2004. Pump was turned off 3:26 p.m., December 9, 2004. Water level was measured in observation well 1 until 10:27 a.m., December 22, 2004. Water level was measured in observation well 2 until 11:55 a.m., December 22, 2004. --, no data]

\begin{tabular}{|c|c|c|c|c|c|c|c|}
\hline \multicolumn{4}{|c|}{ Observation well 1} & \multicolumn{4}{|c|}{ Observation well 2} \\
\hline $\begin{array}{l}\text { Time since } \\
\text { beginning } \\
\text { of aquifer } \\
\text { test (days) }\end{array}$ & $\begin{array}{l}\text { Draw- } \\
\text { down } \\
\text { (feet) }\end{array}$ & $\begin{array}{c}\text { Recovery } \\
\text { (feet) }\end{array}$ & $\begin{array}{c}\text { Elevation } \\
\text { above North } \\
\text { American } \\
\text { Vertical Da- } \\
\text { tum of } 1988 \\
\text { (feet) }\end{array}$ & $\begin{array}{l}\text { Time since } \\
\text { beginning } \\
\text { of aquifer } \\
\text { test (days) }\end{array}$ & $\begin{array}{l}\text { Draw- } \\
\text { down } \\
\text { (feet) }\end{array}$ & $\begin{array}{l}\text { Recovery } \\
\text { (feet) }\end{array}$ & Elevation (feet) \\
\hline 3.239 & 34.05 & -0.13 & 730.27 & 3.352 & 34.27 & 1.10 & 745.54 \\
\hline 3.240 & 34.05 & -.13 & 730.27 & 3.364 & 34.07 & 1.30 & 745.74 \\
\hline 3.241 & 34.05 & -.13 & 730.27 & 3.376 & 33.85 & 1.53 & 745.97 \\
\hline 3.243 & 34.05 & -.13 & 730.27 & 3.390 & 33.61 & 1.77 & 746.21 \\
\hline 3.246 & 34.05 & -.13 & 730.27 & 3.405 & 33.33 & 2.04 & 746.48 \\
\hline 3.249 & 34.05 & -.13 & 730.27 & 3.421 & 33.05 & 2.32 & 746.76 \\
\hline 3.256 & 34.03 & -.12 & 730.29 & 3.438 & 32.74 & 2.64 & 747.08 \\
\hline 3.260 & 34.02 & -.10 & 730.30 & 3.457 & 32.39 & 2.99 & 747.43 \\
\hline 3.264 & 34.00 & -.08 & 730.33 & 3.476 & 32.02 & 3.36 & 747.80 \\
\hline 3.269 & 33.97 & -.05 & 730.36 & 3.498 & 31.62 & 3.76 & 748.20 \\
\hline 3.274 & 33.93 & -0.01 & 730.39 & 3.522 & 31.20 & 4.18 & 748.62 \\
\hline 3.280 & 33.88 & .04 & 730.44 & 3.547 & 30.74 & 4.63 & 749.07 \\
\hline 3.285 & 33.83 & .09 & 730.49 & 3.574 & 30.26 & 5.12 & 749.56 \\
\hline 3.292 & 33.76 & .16 & 730.57 & 3.603 & 29.75 & 5.62 & 750.06 \\
\hline 3.298 & 33.69 & .23 & 730.64 & 3.635 & 29.21 & 6.17 & 750.61 \\
\hline 3.306 & 33.59 & .33 & 730.73 & 3.670 & 28.63 & 6.74 & 751.18 \\
\hline 3.314 & 33.48 & .44 & 730.84 & 3.706 & 28.05 & 7.33 & 751.77 \\
\hline 3.322 & 33.36 & .56 & 730.96 & 3.746 & 27.44 & 7.93 & 752.37 \\
\hline 3.332 & 33.22 & .69 & 731.10 & 3.790 & 26.82 & 8.56 & 753.00 \\
\hline 3.342 & 33.07 & .85 & 731.25 & 3.836 & 26.19 & 9.19 & 753.63 \\
\hline 3.353 & 32.89 & 1.03 & 731.43 & 3.887 & 25.53 & 9.85 & 754.29 \\
\hline 3.364 & 32.70 & 1.21 & 731.62 & 3.941 & 24.87 & 10.51 & 754.95 \\
\hline 3.377 & 32.49 & 1.43 & 731.83 & 4.000 & 24.20 & 11.18 & 755.62 \\
\hline 3.391 & -- & 1.67 & 732.07 & 4.063 & 23.47 & 11.91 & 756.35 \\
\hline 3.405 & 31.99 & 1.93 & 732.33 & 4.132 & 22.73 & 12.65 & 757.09 \\
\hline 3.421 & 31.72 & 2.20 & 732.60 & 4.205 & 21.99 & 13.38 & 757.82 \\
\hline 3.438 & 31.42 & 2.50 & 732.91 & 4.285 & 21.25 & 14.12 & 758.56 \\
\hline 3.457 & 31.08 & 2.83 & 733.24 & 4.371 & 20.54 & 14.84 & 759.28 \\
\hline 3.477 & 30.71 & 3.21 & 733.61 & 4.465 & 19.78 & 15.59 & 760.04 \\
\hline 3.498 & 30.33 & 3.59 & 734.00 & 4.565 & 18.99 & 16.39 & 760.83 \\
\hline
\end{tabular}


Table A3. Measured water levels in observation well 1 and observation well 2, Shakopee Mdewakanton Sioux Community, southeastern Minnesota, December 6-22, 2004.-Continued

[Aquifer test began 10:30 a.m., December 6, 2004. Pump was turned off 3:26 p.m., December 9, 2004. Water level was measured in observation well 1 until 10:27 a.m., December 22, 2004. Water level was measured in observation well 2 until 11:55 a.m., December 22, 2004. --, no data]

\begin{tabular}{|c|c|c|c|c|c|c|c|}
\hline \multicolumn{4}{|c|}{ Observation well 1} & \multicolumn{4}{|c|}{ Observation well 2} \\
\hline $\begin{array}{l}\text { Time since } \\
\text { beginning } \\
\text { of aquifer } \\
\text { test (days) }\end{array}$ & $\begin{array}{l}\text { Draw- } \\
\text { down } \\
\text { (feet) }\end{array}$ & $\begin{array}{c}\text { Recovery } \\
\text { (feet) }\end{array}$ & $\begin{array}{c}\text { Elevation } \\
\text { above North } \\
\text { American } \\
\text { Vertical Da- } \\
\text { tum of } 1988 \\
\text { (feet) }\end{array}$ & $\begin{array}{l}\text { Time since } \\
\text { beginning } \\
\text { of aquifer } \\
\text { test (days) }\end{array}$ & $\begin{array}{l}\text { Draw- } \\
\text { down } \\
\text { (feet) }\end{array}$ & $\begin{array}{c}\text { Recovery } \\
\text { (feet) }\end{array}$ & Elevation (feet) \\
\hline 3.522 & 29.90 & 4.02 & 734.42 & 4.673 & 18.16 & 17.21 & 761.66 \\
\hline 3.547 & 29.46 & 4.46 & 734.87 & 4.790 & 17.30 & 18.08 & 762.52 \\
\hline 3.574 & 28.98 & 4.94 & 735.34 & 4.917 & 16.47 & 18.90 & 763.34 \\
\hline 3.604 & 28.48 & 5.44 & 735.85 & 5.054 & 15.64 & 19.74 & 764.18 \\
\hline 3.636 & 27.94 & 5.98 & 736.39 & 5.200 & 14.75 & 20.63 & 765.07 \\
\hline 3.670 & 27.37 & 6.55 & 736.95 & 5.360 & 13.88 & 21.50 & 765.94 \\
\hline 3.707 & 26.78 & 7.13 & 737.54 & 5.532 & 13.08 & 22.30 & 766.74 \\
\hline 3.747 & 26.17 & 7.75 & 738.15 & 5.717 & 12.21 & 23.17 & 767.61 \\
\hline 3.790 & 25.56 & 8.36 & 738.77 & 5.917 & 11.48 & 23.90 & 768.34 \\
\hline 3.837 & 24.94 & 8.98 & 739.39 & 6.134 & 10.80 & 24.58 & 769.02 \\
\hline 3.887 & 24.29 & 9.63 & 740.03 & 6.368 & 10.17 & 25.21 & 769.65 \\
\hline 3.942 & 23.63 & 10.29 & 740.70 & 6.620 & 9.63 & 25.74 & 770.18 \\
\hline 4.001 & 22.97 & 10.95 & 741.35 & 6.892 & 8.95 & 26.42 & 770.86 \\
\hline 4.064 & 22.25 & 11.67 & 742.08 & 7.187 & 8.48 & 26.89 & 771.33 \\
\hline 4.132 & 21.53 & 12.39 & 742.79 & 7.507 & 7.92 & 27.46 & 771.90 \\
\hline 4.206 & 20.81 & 13.11 & 743.52 & 7.851 & 7.18 & 28.20 & 772.64 \\
\hline 4.286 & 20.08 & 13.84 & 744.24 & 8.226 & 6.39 & 28.99 & 773.43 \\
\hline 4.372 & 19.38 & 14.54 & 744.94 & 8.622 & 5.68 & 29.70 & 774.14 \\
\hline 4.465 & 18.65 & 15.27 & 745.67 & 9.049 & 4.91 & 30.47 & 774.91 \\
\hline 4.565 & 17.89 & 16.03 & 746.43 & 9.517 & 4.39 & 30.99 & 775.43 \\
\hline 4.673 & 17.09 & 16.83 & 747.23 & 10.028 & 3.97 & 31.41 & 775.85 \\
\hline 4.791 & 16.25 & 17.67 & 748.08 & 10.570 & 3.59 & 31.79 & 776.23 \\
\hline 4.917 & 15.47 & 18.45 & 748.85 & 11.153 & 2.90 & 32.48 & 776.92 \\
\hline 5.054 & 14.68 & 19.24 & 749.64 & 11.788 & 2.32 & 33.06 & 777.50 \\
\hline 5.202 & 13.83 & 20.09 & 750.50 & 12.476 & 2.28 & 33.10 & 777.54 \\
\hline 5.360 & 13.00 & 20.92 & 751.32 & 13.215 & 1.75 & 33.62 & 778.06 \\
\hline 5.533 & 12.25 & 21.67 & 752.07 & 14.007 & .89 & 34.48 & 778.93 \\
\hline 5.718 & 11.43 & 22.48 & 752.89 & 14.872 & .72 & 34.65 & 779.09 \\
\hline 5.918 & 10.75 & 23.17 & 753.57 & 15.799 & .68 & 34.69 & 779.13 \\
\hline 6.134 & 10.13 & 23.79 & 754.19 & 16.059 & .66 & 34.71 & 779.15 \\
\hline
\end{tabular}


Table A3. Measured water levels in observation well 1 and observation well 2, Shakopee Mdewakanton Sioux Community, southeastern Minnesota, December 6-22, 2004.-Continued

[Aquifer test began 10:30 a.m., December 6, 2004. Pump was turned off 3:26 p.m., December 9, 2004. Water level was measured in observation well 1 until 10:27 a.m., December 22, 2004. Water level was measured in observation well 2 until 11:55 a.m., December 22, 2004. --, no data]

\begin{tabular}{|c|c|c|c|c|c|c|c|}
\hline \multicolumn{4}{|c|}{ Observation well 1} & \multicolumn{4}{|c|}{ Observation well 2} \\
\hline $\begin{array}{l}\text { Time since } \\
\text { beginning } \\
\text { of aquifer } \\
\text { test (days) }\end{array}$ & $\begin{array}{l}\text { Draw- } \\
\text { down } \\
\text { (feet) }\end{array}$ & $\begin{array}{c}\text { Recovery } \\
\text { (feet) }\end{array}$ & $\begin{array}{c}\text { Elevation } \\
\text { above North } \\
\text { American } \\
\text { Vertical Da- } \\
\text { tum of } 1988 \\
\text { (feet) }\end{array}$ & $\begin{array}{l}\text { Time since } \\
\text { beginning } \\
\text { of aquifer } \\
\text { test (days) }\end{array}$ & $\begin{array}{l}\text { Draw- } \\
\text { down } \\
\text { (feet) }\end{array}$ & $\begin{array}{c}\text { Recovery } \\
\text { (feet) }\end{array}$ & Elevation (feet) \\
\hline 6.368 & 9.57 & 24.35 & 754.75 & & & & \\
\hline 6.620 & 9.08 & 24.84 & 755.24 & & & & \\
\hline 6.893 & 8.46 & 25.46 & 755.86 & & & & \\
\hline 7.187 & 8.04 & 25.88 & 756.28 & & & & \\
\hline 7.509 & 7.54 & 26.37 & 756.78 & & & & \\
\hline 7.852 & 6.85 & 27.07 & 757.47 & & & & \\
\hline 8.227 & 6.10 & 27.82 & 758.23 & & & & \\
\hline 8.623 & 5.42 & 28.50 & 758.91 & & & & \\
\hline 9.050 & 4.68 & 29.24 & 759.65 & & & & \\
\hline 9.519 & 4.18 & 29.74 & 760.14 & & & & \\
\hline 10.019 & 3.78 & 30.14 & 760.54 & & & & \\
\hline 10.571 & 3.42 & 30.50 & 760.90 & & & & \\
\hline 11.155 & 2.72 & 31.20 & 761.60 & & & & \\
\hline 11.790 & 2.15 & 31.77 & 762.18 & & & & \\
\hline 12.467 & 2.12 & 31.80 & 762.21 & & & & \\
\hline 13.207 & 1.59 & 32.33 & 762.73 & & & & \\
\hline 14.009 & .71 & 33.21 & 763.61 & & & & \\
\hline 14.873 & .53 & 33.39 & 763.80 & & & & \\
\hline 15.800 & .47 & 33.44 & 763.85 & & & & \\
\hline 16.019 & .47 & 33.45 & 763.86 & & & & \\
\hline
\end{tabular}

